\title{
Replacing Members with Managers? Mutualism among Membership and Nonmembership Advocacy Organizations in the United States ${ }^{1}$
}

\author{
Edward T. Walker \\ University of Vermont \\ John D. McCarthy \\ Pennsylvania State University \\ Frank Baumgartner \\ University of North Carolina-Chapel Hill
}

\begin{abstract}
Associations with a professional staff but no members (nonmembership advocacy organizations, or NMAOs) are the subject of lively debate. Many argue that their proliferation has allowed an expansion of advocacy without an accompanying growth in civic engagement. This article asks if there has been significant recent growth of NMAOs and if those organizations have displaced membership advocacy organizations (MAOs). The authors find no evidence for a proportional increase of NMAOs since the 1960s. Further, among all organizations in three populations-peace, women's issues, and human rights-NMAOs have not displaced MAOs. In particular, the authors find that MAO density shapes NMAO founding, as membership groups provide a base for professional advocacy. These findings challenge the notion that U.S. civic life has undergone a systemic transformation away from organizational forms that promote civic engagement.
\end{abstract}

\section{INTRODUCTION}

Beginning in the early 1970s, American social scientists started to seek an explanation of an emergent puzzle. While the pace of U.S. citizen

\footnotetext{
${ }^{1}$ The authors would like to thank the following individuals for helpful feedback on earlier manuscript drafts and presentations of the findings: Jerry Davis, Rachel Einwohner, Scott Feld, Rick Hall, Michael Heaney, Jacob Hibel, Randy Hodson, Richard
} 
advocacy, by many indicators, appeared to be quickening during the long decade of the 1960s, it appeared that civic engagement was not keeping pace. The first approximation to a solution to the puzzle implicated the growth of professional advocacy organizations, or those led by experts who mobilized support through a variety of new channels, but mostly did not enlist member participation through dense local groups (McCarthy and Zald 1973). So, while surveys of individual participation and records of membership in voluntary associations do not reflect a strong suprt in civic engagement after the 1960s, there was, no doubt, an efflorescence of new citizen advocacy groups; these were more systematically documented, first, by political scientist Jack Walker $(1983,1991)$ and then more thickly corroborated by a number of subsequent researchers. Some scholars of interest groups continued to misread that rapid growth of advocacy groups as an indicator of increasing citizen engagement, however: "In fact, a participation revolution has occurred in the country as large numbers of citizens have become active in ever-increasing number of protest groups, citizens' organizations and special interest groups" (Loomis and Cigler 1995, p. 10).

In the late 1990s, two well-known Harvard scholars, Theda Skocpol and Robert Putnam, sparked what has become an expanding debate about the decline of civic engagement in the United States: Skocpol from the perspective of trends in voluntary associations and Putnam from the perspective of trends in individual civic engagement. Both pointed to the profusion of professional advocacy organizations with no members or with members who are very weakly connected to organizational leadership, two types of groups they saw as deeply implicated in the stagnation, if not decline, of civic engagement.

Yet there is no systematic assessment of this central premise in this widely accepted portrait of the expansion and role of nonmembership advocacy organizations in arguments for the transformation of civic engagement in the United States in recent decades. In this article we fill this void by presenting systematic evidence, drawn from the Encyclopedia of Associations, about the founding and density of citizen advocacy organizations during the past four decades in order to assess (1) whether the rate of founding of memberless advocacy organizations has increased

Hogan, Erik W. Johnson, Howard Kimeldorf, Calvin Morrill, Hans Noel, Jason OwenSmith, Silvia Pedraza, Fabio Rojas, Vincent Roscigno, Sarah Soule, Jackie Smith, Patricia Strach, Kiyo Tsutsui, Bert Useem, and Mayer Zald. The usual disclaimers apply. Portions of the work reported here were supported by National Science Foundation grant SES-0111443, with Bryan D. Jones. The lead author acknowledges the support of the Robert Wood Johnson Foundation. Neither the NSF nor the RWJF bears responsibility for the analysis reported. Direct correspondence to: Edward T. Walker, University of Vermont, 31 South Prospect Street, Burlington, Vermont 05405. E-mail: Edward.Walker@uvm.edu 
relative to that of membership organizations, (2) the extent to which the density of memberless advocacy organizations relative to that of membership organizations has increased or declined over that time period, and (3) whether there is evidence that the rate of founding of memberless organizations suppresses the rate of founding of membership organizations. We refer to the latter as the replacement hypothesis.

\section{GROWTH IN THE ADVOCACY GROUP SECTOR}

We focus our attention in this article on what we have been calling advocacy organizations or groups. In so doing, we follow the synthetic lead of Kenneth Andrews and Bob Edwards (2004), who recently completed a systematic review of three quite separate but parallel literatures on interest groups, social movement organizations, and nonprofit organizations. They make a convincing argument that "overall, there is substantial common ground in conceptual definitions" among these literatures, leading them to define advocacy organizations as those "that make public interest claims either promoting or resisting social change that, if implemented, would conflict with the social, cultural, political or economic interests or values of other constituencies or groups" (p. 485).

Jack Walker's $(1983,1991)$ early and still widely influential attempt to map the extent of and the changes in the interest group sector in Washington, D.C., estimated that advocacy groups—or what he called citizens' groups-made up approximately $20 \%$ of associations in 1980; the rest were primarily trade associations and professional associations. He further concluded, by analyzing the founding dates of the 564 organizations he surveyed, that there had been a rapid burst of new citizens' groups during the 1960s and 1970s. ${ }^{2}$ Walker included only groups with members in his study, although he did include organizations whose members were other organizations.

Walker's data were later reanalyzed by Baumgartner and Leech (1998, p. 11) who found a $180 \%$ increase in citizens' groups between 1960 and 1985 of $180 \%$ compared to a $47 \%$ increase in trade associations and a $65 \%$ increase in professional associations. These authors went on to illustrate the similarity of these trends to those seen among equivalent subgroups of associations listed in the Encyclopedia of Associations, a publication whose estimates avoid the bias created by omitting certain nonsurviving organizations (i.e., left censoring). These more systematic

\footnotetext{
${ }^{2}$ Walker (1991) acknowledged that his estimates were vulnerable to the left-censoring that resulted from having only information about groups existing in 1980 and ignoring, then, what might have been differential rates of organizational disbanding among the three types of groups.
} 
efforts to document the explosion of advocacy groups in the closing decades of the 20th century were consistent with more anecdotal approaches, generating a wide consensus that such an "explosion" had taken place.

Subsequently, an expanding scholarly dialogue has documented the increasing prevalence and political influence of advocacy "associations without members" in the closing decades of the 20th century (Gray and Lowery 1996; Weir and Ganz 1997, p. 156; Skocpol 1999a, 1999b, 2003, 2004a, 2004b; Edwards and Foley 2002, p. 101; Skocpol, Cobb, and Klofstad 2005; Eikenberry 2007; Strolovitch 2007; Minkoff, Aisenbrey, and Agnone 2008), from international nongovernmental organizations (Boli and Thomas 1997; Keck and Sikkink 1998) to think tanks and policyplanning organizations (Peschek 1987; McGann 1992; Rich 2004) to Washington advocacy organizations concerned with postmaterial issues (Berry 1999). These groups have become a prominent force in American society and politics and have undoubtedly increased in number among the population of organizations engaged in voicing the concerns of citizens in public affairs (Skocpol 1999a, 1999b, 2003, 2004a, 2004b). As Skocpol (2004a, p. A6) puts it, "voluntary groups founded in the 1970s and '80s adopted new forms of organization. Some- such as public law groups, think tanks, foundations, and political action committees-are not actually membership groups at all. And many others are staff-centered associations that have few, if any, chapters and recruit most supporters individually via the mail or media messages."

From one side, the recent dialogue has emphasized that NMAOs represent a relatively novel form of organization and that their proportion in the "cause-oriented" organizational field has increased dramatically since the 1970s (Skocpol 2003, p. 163). Minkoff et al. (2008, p. 527) point out that the new advocacy environment is often seen, in much recent scholarship, as having a problem of "voice without variety." The theoretical suggestion here is that "significant resource and political constraints . . . tend to promote a great deal of similarity—or, isomorphism—among organizations and . . . a higher level of structuration in the organizational field and very little diversity in organizing models" (p. 527). In this process, professional advocates are believed to have displaced the central role of traditional membership organizations. ${ }^{3}$ Underlying this discussion is the

\footnotetext{
${ }^{3}$ We should note that much of this research and commentary emphasizes changes within membership organizations, which are increasingly professionalized and do less to promote face-to-face participation in local, state, or regional chapters (Weir and Ganz 1997; Skocpol 2003). That is, the "members" of modern membership associations may now be increasingly similar to the "supporters" of nonmembership organizations. Such claims about the field of membership organizations, while worthy of further scholarly attention, are beyond the empirical scope of the present analyses. However, we return to this issue in the penultimate section.
} 
notion that this novel form of mobilization has troubling representational consequences, since these groups are only loosely connected to the public. Membership organizations, by contrast, have traditionally provided a crucial link between members of the public and the Washington policy process, while also providing opportunities for citizens to engage directly with one another in local settings; their decline and reorganization have been tied to increasing inequalities in both participation and representation (Skocpol 2004b). The decline of traditional membership organizations and their replacement by professional advocates are therefore related to the decline in civic capacity. But is such replacement taking place?

Robert Putnam (1995, 2000) approached the puzzle from a different direction, first exhaustively identifying trends that show the decline of individual citizen engagement during the last decades of the 20th century. From another side, he has explored a diverse array of explanations of the decline he documents, almost all of them at the individual level of analysis, paying somewhat less attention to what sociologists and political scientists have increasingly come to know as the availability of "opportunities to participate" that advocacy organizations can provide. We argue that advocacy organizations could play a crucial role in accounting for changing levels of civic engagement: to the extent that advocacy organizations provide fewer opportunities to participate, then the changing demography of organizational forms may be an important element in explaining declines in civic engagement. In Bowling Alone (2000), Putnam's account of the decline of civic engagement, he endorses a version of the replacement hypothesis to the puzzle of apparently increasing numbers of advocacy organizations occurring at the same time that levels of civic engagement are declining. Indeed, he attributes these changes to the considerable growth of "tertiary" organizations in which "'membership' is essentially an honorific rhetorical device for fundraising" (p. 156). A replacement argument is consistent with Putnam's, in that he emphasizes the emergence of memberless advocacy organizations, although he certainly does not directly advance many general claims about the changing demography of advocacy organizational forms. Nevertheless, in concert with Skocpol's influential argument, more or less explicit empirical claims about memberless organizations in the evolution of the advocacy organizational sector in recent decades have pervaded much of the discussion about civic engagement in the United States (e.g., Gray and Lowery 1996; Edwards and Foley 2002, p. 101; Andrews and Edwards 2004, p. 488; Eikenberry 2007; Strolovitch 2007; Minkoff et al. 2008) and in transnational advocacy (Smith 2005), and the changing context of membership organizations is also well documented (e.g., Shaiko 1999; Bosso 2003; Sampson et al. 2005; Sobieraj 2006; Howard and Gilbert 2008). Marshall 
Ganz, for instance, has gone so far as to refer to nonmembership organizations as "bodyless heads" (according to Skocpol [2003, p. 163]).

While analysts of civic engagement and political participation have argued that the memberless organizational form is relatively novel, analysts of social movements and advocacy organizations have recognized that staff-dominated groups have long played an active role in advocacy, from policy institutes founded by former movement leaders (Meyer and Whittier 1994, p. 288) to legal defense funds (Tauber 1998) to national networks that train cadres for grassroots community organizations (Delgado 1986; Warren 2001). Similarly, Minkoff et al. (2008) find that more than one-third of the advocacy field consists of nonmembership groups: about one in four is a centralized nonmembership organization (such as the Center for Responsive Politics); an additional 10\% are nonmembership networks with chapters (such as the AIDS Action Council). Political scientists have also long recognized the importance of diverse organizational forms, particularly nonmembership "institutions," in government advocacy (Salisbury 1984; Lowery and Gray 1998). So memberless advocacy organizations, this research implies, are neither a novel organizational form nor one that necessarily plays a proportionally larger role among modern advocacy organizations. Instead of replacing membership organizations, then, nonmembership advocacy organizations (NMAOs) may instead play a complementary role in advocacy, if not also in the direct mobilization of citizen engagement.

Our research asks two questions about memberless advocacy organizations. First, despite the increasing attention paid to nonmembership advocacy organizations in studies of civic engagement and the voluntary sector, there has yet to be a systematic examination of whether these organizations are, in fact, an increasing portion of the advocacy associational community. Does systematic evidence support this claim? It seems more than appropriate, then, to consider whether NMAOs have grown as a proportion of the organizational population of advocacy groups active in public affairs. Second, in line with the contending perspectives outlined above, we also test the argument that NMAOs have been replacing membership organizations. Are such associations a competing organizational form, effectively squeezing out traditional membership groups, or are they complementary, developing alongside membership groups, interacting with them and emerging from similar environmental contexts?

In the present analysis, we examine the growth of the memberless organizational form both in the broader field of advocacy associations and, more specifically, in organizations active in three of the most prominent and contested issue arenas in the United States during the last 40 years: peace issues, women's issues, and human rights issues. We explain the logic and method of our selection of these three populations for analysis 
in later discussion. We employ data gathered from the complete public affairs section of the Encyclopedia of Associations over the period 196597. This time period captures the key years of changing civic organization in the United States, as documented by a variety of observers (Walker 1991; Berry 1997; Weir and Ganz 1997; Skocpol 1999a), although it omits the very recent years in which the expansion of Internet and communications technologies have further lowered the costs of collective action (Howard 2006). As the public affairs section of the Encyclopedia is a relatively comprehensive catalogue of national advocacy organizations in these three issue arenas, it is an appropriate source of data on both membership and staff-only associations; for a full description of this data source and the extent to which it can be taken as representative of national advocacy organizations in the United States, we direct readers to the appendix.

We begin by reviewing claims about the expansion and proportional representation of nonmembership advocacy associations since the 1960s. We then propose a strategy for assessing our claim that the density of each kind of association may actually enhance rather than inhibit the rate of founding of the other. Next, we describe the data sources and specific variables we bring to bear in understanding the macro-organizational dynamics (Minkoff 2002) of membership organizations and NMAOs in these three advocacy organization populations. In turn, we analyze the patterns of founding of memberless organizations using data on the density of organizations in each issue sector, along with controls for government attention to the issue in question, the resource environment, and media attention. We conclude by discussing the broader implications of this study for research on civic engagement and voluntary associations.

\section{NONMEMBERSHIP ADVOCACY ORGANIZATIONS}

Associations without members appear, to many observers, to have increased in number in recent decades, but such associations have long been among the most active in interest group populations (Salisbury 1984; Lowery and Gray 1998). Although their recent numeric growth may have heightened the absolute level of influence of such groups, public affairs organizations driven entirely by the efforts of paid staff have been a significant force in advocacy since long before the U.S. "interest group explosion" (Walker 1991; Berry 1997) of the 1970s and 1980s. Professionalized social movement organizations have been regular participants in a variety of advocacy organization populations and, others have illustrated, have helped to sustain movements during periods of decline and abeyance (Taylor 1989) and help to develop support among those advo- 
cates of a movement's cause who would prefer to abstain from direct engagement (McCarthy and Zald 1977). Indeed, as we maintain here, there is good reason to believe that membership and nonmembership organizations play complementary rather than competitive roles, just as service providers - such as movement-related cultural groups, educational institutions, and publishing houses - tend to undergird the regular activism of the primary organizations active in social movements (Della Porta and Diani 1999, p. 146).

The common image in scholarly discourse of memberless associations is of a group that relies almost entirely on direct mail, telemarketing, and advocacy advertising in order to provoke a distant constituency into writing a check to the organization or, perhaps more significantly, contacting their representatives to support the group's issue positions. These organizations are thought to be heavily focused on national politics-many of the largest such groups have headquarters in Washington, D.C.- and to mobilize individuals in their local communities mainly in order to make them a force in national-level politics through grassroots lobbying. Memberless organizations, relying as they do on paid staff members, are purported to have grown in political significance in response to the changing patterns of professional and elite political participation (Skocpol 1999a, 2003). Because many such organizations have only a "paper" constituency, their advocacy efforts are, at times, accused of lacking authenticity or even of being "Astroturf" (i.e., a "fake" grassroots organization in which participants either are fictional or were apparently misled into participating; Loomis and Cigler 1995). Some, such as David Horowitz's (now defunct) Center for the Study of Popular Culture, are little more than unanchored organizational names useful in the attribution of quotes in media reports. Jack Walker (1991) noted that many organizations active in the Washington advocacy community were, in fact, mobilized almost entirely through the efforts of elite-led organizational structures rather than arising spontaneously from popular demands. Wealthy patrons could fund advocacy organizations, and these groups might or might not later develop strong membership bases. Grant Jordan and William Maloney (1997) have even noted the degree to which organizational leaders may often launch lobbying efforts and media-savvy protest campaigns for the sole purpose of generating more check writing and anxiety from supportive members of the public, effectively turning the relation between lobbying activity and social mobilization on its head. So the links between the public and those organizations purporting to speak for them have been shown to follow many patterns, and scholars have-both implicitly and explicitly_raised normative questions about the rise of "associations without members." In fact, however, we know little about whether these 
groups complement or, instead, compete with traditional member-based organizations.

On the basis of a 1985 survey, Frank Baumgartner and Jack Walker showed that large proportions of Americans are financial contributors to various associations without considering themselves to be "members." They compared survey results from the traditional question wording about membership in interest groups (see Verba and Nie 1972) to a more encompassing question that also asked, "Are you an active member, a non-active member, or have you given money only?" Inclusion of "contributors" more than doubled the total number of group affiliations beyond including only members (Baumgartner and Walker 1988, p. 921). ${ }^{4}$ Of course, contributors were especially common among some types of organizations, such as charities; however, "issue" groups more than doubled, and even church groups had substantial increases when this broader definition of citizen linkage to the associational universe was used. By the 1980s, it was clear that a broad range of forms of organizational affiliation were possible, from traditional membership to looser forms of affiliation through financial contributions, and of course these trends have certainly increased in the decades since this study. All of this motivates the current study. Organizational leaders seeking to build connections with their potential constituents through e-mail, Twitter, and Facebook connections certainly do so with the expectation that these connections will reinforce rather than replace their other connections.

Although certainly not an "Astroturf" organization in any sense of the term, the prototype of this organizational form in dominant accounts of memberless advocacy is the Children's Defense Fund (see Skocpol 1999b, 2003, pp. 199-200). The CDF began in 1973 as a nonprofit organization engaged in advocacy on a variety of issues related to the health, education, and socialization of children, especially poor and/or minority children. The organization's founder and president is Marion Wright Edelman, who first went to Washington as part of the legal counsel for Martin Luther King's 1968 Poor People's Campaign. ${ }^{5}$ Edelman had prior experience working in perhaps the most important nonmembership organization of the Civil Rights movement, the NAACP Legal Defense and Educational Fund (on the fund, see Jenkins and Eckert [1986]; Tauber [1998]). Since 1973, the CDF has engaged in research on the needs of children, program evaluation, lobbying campaigns on behalf of children's issues, and the creation of coalitions between community organizations and state and local governments. The organization is driven by the efforts

\footnotetext{
${ }^{4}$ Their table 4 shows 928 members but 2,033 affiliates when contributors are included.

${ }^{5}$ This discussion builds on the official website of the CDF (http://www.childrensdefense .org/site/PageServer?pagename = People_MWE).
} 
of paid staff and heavily focused on Washington lobbying and claims numerous legislative and budgetary victories on behalf of children in the over 30 years since its inception. ${ }^{6}$ The $\mathrm{CDF}$ is perhaps the prototypical example of what we refer to as a Washington advocate organization. ${ }^{7}$

Interestingly, the case of the CDF helps to illustrate the ambivalent relationship between nonmembership groups and membership organizations. On the one hand, groups that focus on inside lobbying and rely more heavily on professional staff may be more likely to find financial support from outside institutions (Jenkins and Halcli 1999) and thereby encourage newcomers to adopt such structures for instrumental purposes. At the same time, however, these two types can be conceptualized as two organizational repertoires (Clemens 1998; McCarthy and Walker 2004) or models that can be adapted to work toward similar social change goals; the division of labor between these two organizational forms may instead be quite productive and complementary.

We examine the relationship between membership- and nonmembership-based advocacy groups in the entire population of organizations active in public affairs, as well as in the particular issue domains of women's issues, human rights, and peace. We selected these three issues for analysis because they constitute three of the most prominently represented advocacy organizational populations included in our data source, and, more important, they represent three of the most significant social movement fields in the late 20th century; advocacy organizations in these fields have, respectively, pressed for equal opportunity laws and challenged gender discrimination (Mansbridge 1986), called attention to abuses of power and crimes against humanity across the globe (Keck and Sikkink 1998), and changed the terms of the policy debates over wars in Vietnam (McAdam and Su 2002), nuclear policy (Meyer 1990), and the Cold War (Edwards and Marullo 1995).

On the basis of the previous discussion, then, our primary hypothesis is that despite the numeric increase in NMAOs in recent decades, there has been relative stability in the proportion of such organizations in the field of public affairs associations. More explicitly:

HyPOTHESIS 1a.-NMAOs have grown in number between 1965 and 1997 but have not significantly increased in proportional density throughout the field of public affairs associations.

Hypothesis 1b.-NMAOs have grown in number between 1965 and

\footnotetext{
${ }^{6} \mathrm{http} / / / \mathrm{www}$. childrensdefense.org/site/PageServer?pagename = History_Milestones.

${ }^{7}$ However, it is worth noting that, despite CDF's nonmembership structure, it includes state-level chapters that, as Minkoff et al. (2008, p. 240) point out, may make it more accessible to individuals than more centralized NMAOs.
} 
1997 but have not significantly increased in proportional density among women's advocacy associations.

HyPOTHESIS 1c.-NMAOs have grown in number between 1965 and 1997 but have not significantly increased in proportional density among peace advocacy associations.

Hypothesis 1d.-NMAOs have grown in number between 1965 and 1997 but have not significantly increased in proportional density among human rights advocacy associations.

\section{MEMBERSHIP STRUCTURES: COMPETITION OR MUTUALISM?}

We do not intend to develop here a full-blown theoretical account of how issue entrepreneurs select and re-form elements of organizational structure as they craft new organizations (in particular whether or not they choose to enlist constituent members). Instead, we aim to call attention to the direct and indirect cooperative ties between several types of memberless associations and those with members in order to buttress our expectation that NMAOs have been emerging side-by-side with membership organizations in a process of mutual cooperation rather than competition. Once we have done so, we will sketch out an approach to assessing our expectations based on ecological approaches to organizations, especially in regard to the role of cross-densities between interacting organizational populations.

Most accounts of the expansion of memberless associations depend primarily on single organizational cases and anecdotes (McCarthy and Zald 1973; Skocpol 1999b, 2003) and often depict what we call Washington advocates, such as the CDF. However, not all nonmembership organizations, even within advocacy organizational populations, engage in Washington-oriented lobbying. Many are not focused primarily on direct advocacy but assist in the formation of membership organizations in local communities; the reformed Industrial Areas Foundation would be one example (Warren 2001). Still others are funds and foundations that support both service and advocacy within a given issue domain providing services directly to membership advocacy groups. ${ }^{8}$ Given the diverse and often tight interorganizational links that exist among NMAOs and traditional associations, how might we understand the relationship between these two forms? Drawing on work of previous scholars, we investigate how the rates of founding of membership and memberless advocacy organizations within competitive issue arenas affect one another.

The structures that advocacy organizations adopt should be subject to

\footnotetext{
${ }^{8}$ We return to this issue in a later section in which we outline a typology of NMAOs.
} 
significant interorganizational pressures. In particular, we emphasize the role of interorganizational legitimation and competition in structuring advocacy organizational populations, following the lead of organizational ecologists. Scholars have argued that the evolving density of an organizational population often follows an inverted-U-shaped curve because of the existence of density dependence; that is, the fluctuation of the total number of active organizations in the population at a given moment (density) is often critical in shaping the subsequent rates of patterns of founding and mortality in that population (Hannan and Freeman 1989; Hannan and Carroll 1992). This being the case, legitimation processes are crucial to the development of organizational fields, in that the early development of an organizational field tends to be characterized by increasing legitimacy alongside higher population density, as newcomers build on the resources and cultural acceptance already cultivated by existing organizations. Once this legitimacy is widespread, an organizational field can be said to be institutionalized, in which its structures and practices become, to some extent, "taken for granted" (Meyer and Rowan 1977). However, institutionalization does not imply limitless growth of the organizational field since there is a finite supply of resources (financial, moral, and human) available to the entire field; therefore, once the organizational field is well established, interorganizational competitive pressures become more influential in shaping field dynamics, especially patterns of founding and mortality (Hannan and Freeman 1989; Hannan and Carroll 1992).

For our purposes, we call special attention to the pressures that organizational populations exert on other, related populations, through what are referred to as cross-effects between populations (see also Barnett and Carroll 1987; Hannan and Freeman 1987; Baum and Oliver 1991; Rao and Nielsen 1992; Brittain 1994; Minkoff 1994). Assessing cross-density effects allows analysts to test whether the density of one population of organizations may shape the founding and/or disbanding rates of a secondary organizational population. If one tends to find positive crosseffects-that is, increases in density in one population lead to increases in founding (or decreases in disbanding) in the second population-one may infer a mutualistic link between them; however, negative cross-effects suggest that the link is characterized mainly by competition (Minkoff 1994, p. 946). Minkoff, for example, finds a competitive "displacement effect" in which advocacy organizations expanded dramatically, thereby limiting the founding of new service organizations. Similarly, Hannan and Freeman (1989) find that the increasing density of craft unions depressed the founding rate of industrial unions and that higher densities of industrial unions, conversely, reduced the rate of founding of those engaged in craft organizations, thereby suggesting a competitive association. Carroll and 
Wade (1991), however, find a mutualistic relationship between urban and rural microbreweries.

A key theoretical issue in understanding these macro-organizational dynamics regards mutual cooperation and division of labor within diverse organizational populations (Minkoff 1995, 1997; Olzak and Ryo 2007; Soule and King 2008). As Levitsky (2007) points out, while organizational theorists have recognized the potential for organizational populations to have either competitive or cooperative interorganizational relations, scholars of social movements and advocacy have often overlooked the mutual support that diverse organizations provide to one another, focusing instead on how organizations compete over such scarce resources as funding, constituent support and effort, and public attention. There is considerable evidence that advocacy populations benefit by taking a multipronged approach that coordinates professional advocacy_-whether through legal tactics, media strategies, lobbying, or other "insider" means-with member-driven grassroots mobilization (Levitsky 2007; see also McFarland 1984). Thus, even if organizations compete over resources and broader public support, the structural relationship between these two organizational forms appears likely to result in a productive division of labor that helps strengthen associations' aggregate capacity for effective action within their issue domain. ${ }^{9}$

In our case, the examination of cross-effects allows us to consider whether the relationship between membership and nonmembership organizations is either competitive or mutualistic in nature. To the extent that we find positive cross-effects between populations of membership and nonmembership organizations, then, it is reasonable to conclude that NMAOs are not displacing membership organizations but facilitating their emergence. And, as organizational analysts have suggested, mutualism in organizational populations helps to create organizational community and a productive division of labor among groups (Barnett and Carroll 1987). The hypotheses, then, that are at the center of this analysis state our expectation of a mutually supportive relationship. The first of these is the replacement hypothesis described earlier.

Hypothesis 2a.-The founding of membership organizations will be positively influenced by the density of NMAOs in the population, both in the broader field of public affairs associations and among peace, women's, and human rights associations.

НyротнEsis 2b.-The founding of NMAOs will be positively influenced

\footnotetext{
${ }^{9}$ As Minkoff et al. (2008, p. 544) put it, "some forms of organization may be more effective at setting the policy agenda, others at directly influencing decision-makers or ensuring that political gains are consolidated instead of rolled back, and still others at guaranteeing the flow of resources into and across the sector."
} 
by the density of membership organizations in the population, both in the broader field of public affairs associations and among peace, women's, and human rights associations.

Our analyses are designed primarily to assess the interrelated organizational dynamics of membership and nonmembership associations, but also, as a check of the robustness of the findings, we control for governmental attention to each issue, media coverage, and the changing resource environment. Because these controls are peripheral to the primary questions we pose here, we do not generate strong theoretical expectations about their effects. Growing personal income may generate more memberships overall, media coverage may create more interest, and increased government activity in an issue area may cause more interest group mobilization.

\section{DATA SOURCES AND MEASURES}

In order to assess our claims regarding the cross-effects of density that shape associational founding events, we employ data aggregated from the public affairs section of the Encyclopedia of Associations. While the Encyclopedia was not developed with the purpose in mind of serving as a resource for the dynamic study of associational populations, the directory is remarkably consistent over time and captures well the national organizational populations in question (Baumgartner 2005). The data file that we employ for our analyses includes all organizations listed under the heading of public affairs organizations, relying on data collected about such organizations from all editions of the Encyclopedia since the publication of the fifth edition in 1968, up to and including the fortieth edition, published in 2003. The public affairs section of the Encyclopedia includes information about only one out of the 16 organizational sectors into which the directory is organized, but it includes the largest proportion of causeoriented advocacy organizations and social movement organizations. ${ }^{10} \mathrm{Be}-$ yond our three issue domains of primary interest, the public affairs data

\footnotetext{
${ }^{10}$ There are other sections of the Encyclopedia that are also likely to include a number of such organizations. These sections include social welfare; health and medical; foreign interest, nationality, and ethnic organizations; and labor unions. However, for the three issue areas we examine in the present analyses, the public affairs section includes the vast majority of organizations (see the appendix). We recognize, however, that using this subsection is likely to overestimate organizations engaged in advocacy and underestimate the presence of organizations focused on service provision (which are more likely to be categorized instead as social welfare organizations). Similarly, the Encyclopedia is likely to underrepresent small and/or short-lived organizations engaged in these issue areas. We encourage readers to keep in mind these caveats, as well as those highlighted by Brulle et al. (2007), when reviewing our findings.
} 
also include a sizable number of listings for organizations active in making basic ideological claims (e.g., conservative, liberal, libertarian; $12.6 \%$ of organization-edition listings), those expressing concerns about a specific nation or geographic area (13.5\%), and those concerned about a specific racial/ethnic group (3.3\%). In order to carry out the most conservative statistical analyses of the founding patterns of these organizations, we rely only on a restricted temporal portion of the data, including only 196597. We begin in 1965 because doing so allows us to capture the population of organizations founded just prior to the printing of the fifth edition (and just prior to the "explosion" of group founding events identified by other analysts) and end in 1997 because organizations often do not appear in the directory until, on average, approximately six years after their founding (Johnson and McCarthy 2004). ${ }^{11}$ Thus, we do not analyze data on founding events from the most recent years of the Encyclopedia since doing so would likely have led us, inadvertently, to overlook some organizations that have only recently been founded and were not yet listed in the annual volumes.

From this data source we derive our measures of organizational founding and density for the entire field and within the three advocacy issue areas we study: peace, women's issues, and human rights. We focus on these three issue areas because of their prominence in American politics and society in the closing decades of the 20th century. ${ }^{12}$ In order to determine the issue area to which an organization within public affairs belonged, we used the keyword area assigned to the organization in the directory. Peace organizations include those that were listed under any of the following keywords: antidraft or draft, conscientious objectors, disarmament, nuclear war and weapons, peace, war resistance, or youth against war. Women's organizations include the keywords woman/ women, women's rights, feminist/feminism, reproductive rights/freedoms, and sexual harassment. Human rights organizations included the keywords human rights, amnesty, capital punishment, political prisoners, and

\footnotetext{
${ }^{11}$ Although our data on founding include only those organizations that came into existence in 1997 or earlier, we employ all data from the Encyclopedia up to 2003 in order to estimate those founding dates. For example, if an organization was founded in 1996 but did not appear in the directory until 2001, this organization would be included in our data. However, if an organization that was founded in 1998 appeared in 2001, that case would fall outside the range of the time series we analyze.

${ }^{12}$ Civil rights organizations, while among the most prominent in the United States during the period under examination, were not included because of data limitations. The public affairs section of the Encyclopedia does not include a full listing of civil rights organizations since many such groups are instead listed under social welfare. Peace, women's, and human rights organizations, however, are almost exclusively found in the public affairs section of the directory, as we explain in further detail in the appendix.
} 
refugees. As such, our categorization includes all keywords that could reasonably be considered to be associated with each of these issue domains.

In addition to grouping organizations into advocacy issue populations, the present data source also includes information about the organizational structures of each group included from each edition of the Encyclopedia. Organizations were classified into five categories: individual membership, organizational membership, mixed individual-organizational membership, nonmembership, and don't know. Our category of interest, nonmembership organizations, includes all groups in which the Encyclopedia entry fails to reference a member base and whose entry also contains a descriptor such as foundation, institute, center, committee, fund, campaign, program, project, conference, department, task force, or mission. ${ }^{13}$ Additional analyses (not presented) illustrate that certain organizations that have names including these descriptors are, in fact, membership organizations and are coded as such; groups falling in this category include the Citizens' Committee for the Right to Keep and Bear Arms and the Freedom to Read Foundation. Individual membership organizations are those that could be clearly identified as composed of individuals; cases were coded as such if the organization referenced individual members in its statement regarding their membership dues or if the name of the organization made clear that it was composed of individuals (including words such as "citizens," "professionals," "practitioners," and the like). Organizational membership groups include, for example, groups of corporations, hospitals, universities, or other individual membership organizations. Groups of individuals from other organizations (e.g., groups of executive directors of women's nonprofits) were not considered organizational membership groups unless the represented organization itself is a member. Finally, those groups that met the criteria for both individual and organizational membership are placed into the separate category of groups that have a hybrid individual-organizational membership. Those remaining organizations that could not be classified were coded don't know in each organization-edition and are excluded for the purposes of the following analyses. Although we present the distribution of all four membership types in figure 1 below, our statistical analyses group these membership structures into one of two categories: membership and nonmembership. Finally, we include data from the Encyclopedia regarding whether each organization engages in government advocacy in our de-

\footnotetext{
${ }^{13}$ Organizations that are a subsection of, or were established by, membership organizations were included as nonmembership if the group meets the aforementioned criteria.
} 
scriptive analyses below. ${ }^{14}$ Although all organizations in our data advocate for the public or political recognition of a particular issue, only certain organizations engage in formal attempts to advocate their issue before government.

In order to arrive at yearly estimates of the founding of organizations within each population, we used a series of unique identifiers allowing us to aggregate the data into histories for each organization. A team of research assistants sorted cases across Encyclopedia editions by name and location in order to match repeating organizations. Next, each organization was assigned its own unique identifier. Consistent with standard practice in organizational analysis, groups that merged were coded such that the merged organization was treated as the survival of the largest of the merged pair, and the smaller organization was classified as an organizational death. After these identifiers were assigned to each unique organization, we aggregated the data into summaries of each organization's history.

The summary data for each organization use the modal value of the organization's attributes over the years of observation for the purposes of analysis. For a group's membership structure, issue area, and engagement in government advocacy, each organizational case was assigned the modal value of that variable across all of the Encyclopedia years in which the organization appeared. While this methodology underestimates the degree of organizational change in the population, using the modal values suits the primary purpose of our analysis in that it captures each organization's primary structures and activities throughout its life span. Further, since our main goal is to capture the means by which external pressures shape the organizational structures that advocacy organizations adopt and maintain and because over $96 \%$ of the organizations in our data retain an identical structure with regard to the membership/nonmembership distinction that interests us throughout their entire life span, this strategy seems reasonable (cf. Minkoff 1999, p. 1681). ${ }^{15}$

\footnotetext{
${ }^{14}$ For each organization-edition, the data file includes measures of the group's activity with respect to government, independent of that group's membership structure. Groups were considered government advocates if their main purpose or goal is explicitly related to public policy, even if their directory entry does not mention any particular government-related activities. In addition, organizations including any of the following activities in their description were also included: education of the public or policy makers about a policy issue, citizen education, specific pieces of legislation, monitoring legislation or legislative activities, lobbying or electoral campaigns, regulatory agencies or programs, or the establishment of government standards or new government entities. ${ }^{15}$ Some other types of organizational change are slightly more common; in fact when comparing each organization's structure in the first year of our observation to its last year under observation, we find that only $1.85 \%$ of organizations changed from individual membership to nonmembership, and about $1.8 \%$ made the reverse transition.
} 
As for the identification of the founding date, we rely on the modal value reported by the Encyclopedia across organization-editions. Although it is extremely rare for the founding date entries of an organization to be reported inconsistently across years, we rely on the modal value in order to reduce any error associated with conflicting listings. As well, certain cases lack a founding year, often in the earliest years of their existence, perhaps as a strategy to minimize the potential costs to their legitimacy of being recognized as a young organization. Following from the finding of Johnson and McCarthy (2004) that organizations, on average, take about six years from the time of founding until they first appear in the directory, we impute a founding date to all missing cases, using the first year of their appearance in the directory minus six. This imputation was made for $11.5 \%$ of cases, a large proportion of which were organizations first seen in the 2003 edition (28\% of the imputed cases).

Using this comprehensive organization-level data file that aggregates organizational data across all years of the Encyclopedia $(N=4,832)$, we tabulated counts of the number of organizations active in each issue area according to their membership structure and focus on government advocacy. As well, we calculated the density of each of these organizational populations by converting each organization into a series of dummy variables for yearly presence that tracked their life span from their founding year until either their last appearance in the Encyclopedia or rightcensoring and then aggregating these values into annual density estimates for each respective population.

Time-series data structure and measures.-In order to estimate the cross-density effects on rates of founding of memberless associations, we constructed a time-series data file of annual counts of founding events from 1965 to 1997 ( $N=33$ ). As we describe below, our first set of dependent measures is made up of annual measures of the following: the founding of all public affairs organizations, nonmembership public affairs organizations, and the founding of nonmembership public affairs associations that engage in advocacy (see table 2 below). We then carry out analyses that predict and compare the founding of nonmembership and membership organizations within each of the three advocacy populations under consideration, estimating both the standard and cross-effects of density for each organizational form in order to test hypotheses $2 a$ and $2 b$.

In calculating parameter estimates of the factors most influential in shaping the organizational founding, we rely on a number of data sources

Most other organizational change involves organizations adding either individual or organizational members. The overall rate of change, including adding individual or organizational members, was $14.5 \%$. 
beyond those provided by the Encyclopedia, all of which are lagged one year prior to the founding events in question (i.e., from 1964 to 1996). We include measures of the government attention paid to each issue area, general information about the resource environment available to citizens' groups, and media coverage. For further detail about the construction of these measures, see the appendix. As mentioned earlier, these controls are included mainly as a check on the robustness of the major findings.

\section{RESULTS}

\section{Descriptive Statistics}

We began by calling attention to the fact that the NMAOs are not a novel organizational form. First, in order to assess the claim that such professional-only organizations have displaced membership organizations in the associational population, we present a $100 \%$ stacked area chart of the proportional density of each organizational structure across all organizations engaged in public affairs, using counts of organizations from each edition of the Encyclopedia of Organizations.$^{16}$ These results are presented in figure 1 .

As McAdam and Scott argue, "An important indicator of institutional change . . . involves changes over time in the relative numbers of organizations exhibiting a given form" (2005, p. 24; emphasis added). While we know that the population of nonmembership organizations has expanded in number, it is important first to consider the relative proportions of each organizational form in the population. Figure 1 shows that when considered relative to the other organizational forms present in the population of public affairs associations, the proportions of each type have remained relatively constant (in support of hypothesis $1 a$ ). ${ }^{17}$ In fact, the year in which we find the highest proportion of nonmembership orga-

\footnotetext{
${ }^{16}$ The range of years presented in figs. 1 and 6 relies on Encyclopedia edition-years between 1968 and 1998 in order to better capture dynamic change both within and between organizations.

${ }^{17}$ Additional state-level analyses (not shown) provide further support for the expectation of proportionality in hypothesis 1 . For these analyses, we constructed a data file that tracks the numbers of both membership and nonmembership associations within states across editions of the Encyclopedia. Then, for all 21 states that had at least 4 million in population (as of 1980) plus the District of Columbia, we calculated simple correlations between the counts of each organizational type within each state. The average within-state correlation between the count of membership and nonmembership organizations is .708, and many of the most heavily organized and populous states have correlations either in excess of .9 (California, District of Columbia, Virginia, Massachusetts, and Pennsylvania) or greater than .8 (New York, Texas, Ohio, Florida, and Maryland).
} 


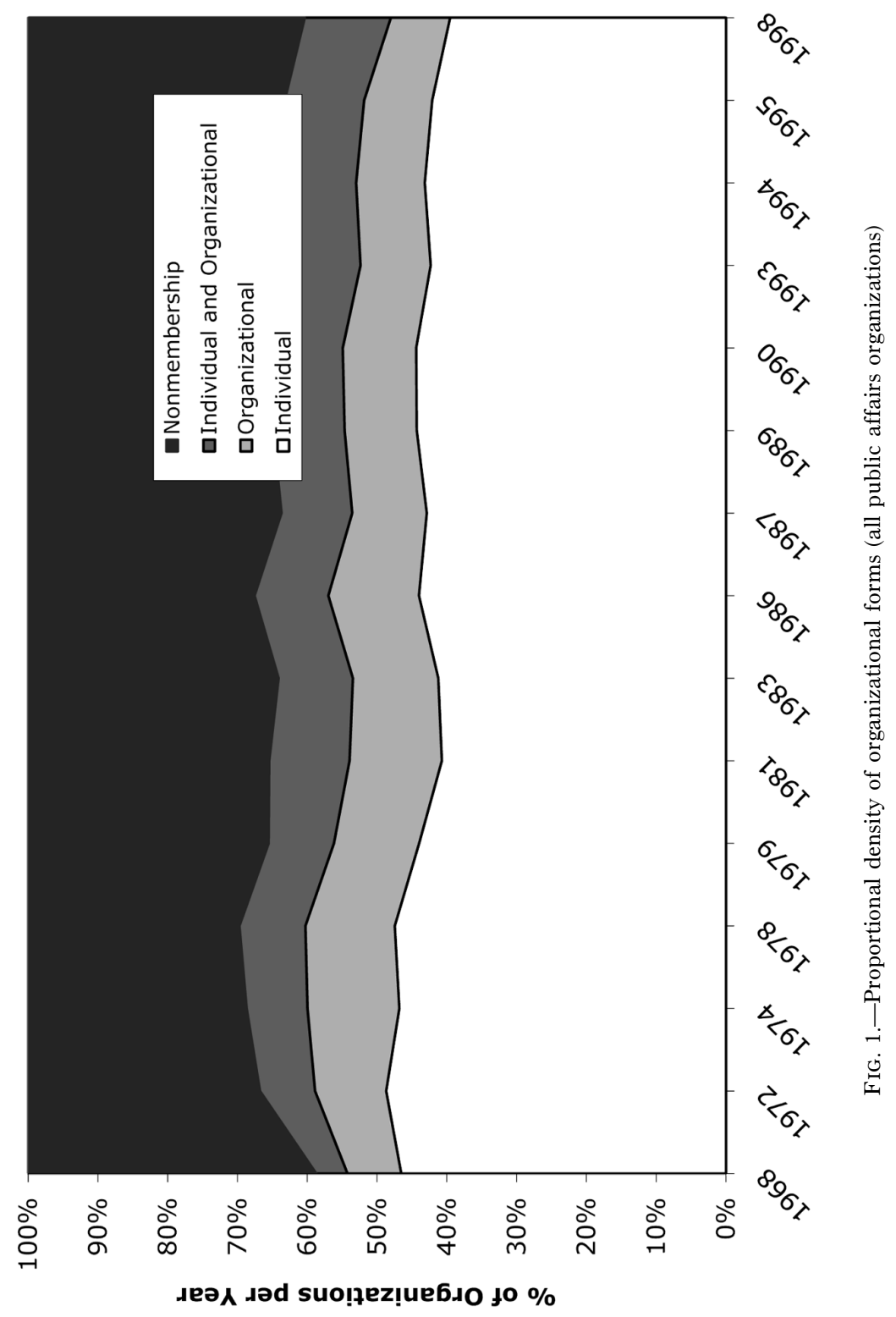


nizations in the population is 1968, not during the years of the "advocacy explosion" of the late 1970s and early 1980s. Figure 1 illustrates that the relative proportions of each organizational structure remain remarkably constant over the period in question, with membership organizations (of all types) constituting between $59 \%$ and $69 \%$ of the organizational population. We therefore find strong evidence that nonmembership organizations have not displaced membership organizations in the population of public affairs organizations (in line with hypothesis 1 a). ${ }^{18}$

Secondarily, these data illustrate that nonmembership organizations have been a consistent, sizable presence in public affairs throughout the past half century. The descriptive statistics in table 1 present even further evidence of this fact. First, the figures in table 1 demonstrate that across the entire time series we examine (1965-97), NMAOs represented $33.4 \%$ of all organizations founded in an average year (39.4/117.8). These findings accord with those of two studies (both of organizations as of the year 2000): Strolovitch (2007, p. 54) found that approximately $37.8 \%$ of advocacy groups had a nonmembership structure, and Minkoff et al. (2008, p. 545) found that $36.4 \%$ of groups were NMAOs. Although, when compared to the density proportions reported in figure 1 and described above, this would appear to suggest that they have a longer life span, additional analyses (not presented) show that nonmembership groups have a slightly shorter life span than individual membership groups. ${ }^{19}$ Interestingly, additional descriptive statistics (not shown) illustrate that the NMAO organizational population is not overwhelmingly dominated by those groups that engage in formal efforts at governmental advocacy, since only $51.3 \%$ of all NMAOs founded in a given year were active in efforts to influence government. Thus, Washington advocates constitute only a portion of the NMAO population, as we describe later.

Table 1 also shows that with respect to the density of organizations within each issue arena, peace has the highest mean annual density (about 121 organizations), which is greater than women's (about 99 organiza-

\footnotetext{
${ }^{18}$ Interestingly, we also find that the median staff sizes are similar across organizational structures. NMAOs have a median staff of six, whereas all three of the other organizational forms-individual only, organizational only, and mixed individual-organizational membership — each have a median staff size of four. Budget sizes differ somewhat dramatically, however, since nonmembership groups are much more heavily resourced, with a median budget of approximately $\$ 318,750$. The other types have the following median budgets: individual only, $\$ 100,000$; organizational only, $\$ 250,000$; and mixed individual-organizational, $\$ 162,917$.

${ }^{19}$ To carry out these analyses, we calculated the mean life span for each organization that was not right-censored. We found the following distribution of life spans across organizational structure: 21.9 years for individual membership groups, 20.5 years for organizational membership, 20.6 years for mixed individual-organizational membership, and 19.4 years for nonmembership groups.
} 
TABLE 1

Descriptive Statistics

\begin{tabular}{|c|c|c|c|c|c|}
\hline & Mean & $\mathrm{SD}$ & Median & Min & Max \\
\hline \multicolumn{6}{|l|}{ Dependent measures (founding events): } \\
\hline \multicolumn{6}{|l|}{ Total public affairs: } \\
\hline All organizations & 117.8 & 63.1 & 114 & 31 & 270 \\
\hline Nonmembership organizations $\ldots$ & 39.4 & 23.0 & 40 & 13 & 100 \\
\hline \multicolumn{6}{|l|}{ Nonmembership advocacy organi- } \\
\hline zations $\ldots \ldots$. & 20.2 & 15.1 & 17 & 4 & 68 \\
\hline \multicolumn{6}{|l|}{ Membership organizations: } \\
\hline Peace $\ldots \ldots \ldots \ldots \ldots \ldots \ldots$ & 5.1 & 5.9 & 3 & 0 & 25 \\
\hline Women's ...... & 4.7 & 3.8 & 3 & 0 & 12 \\
\hline Human rights & 2.4 & 2.4 & 2 & 0 & 9 \\
\hline \multicolumn{6}{|l|}{ Nonmembership organizations: } \\
\hline Peace & 2.3 & 3.1 & 2 & 0 & 13 \\
\hline Women's & 2.2 & 2.4 & 1 & 0 & 10 \\
\hline Human rights & 1.4 & 1.2 & 1 & 0 & 4 \\
\hline \multicolumn{6}{|l|}{ Independent measures $(t-1)$ : } \\
\hline \multicolumn{6}{|l|}{ Organizational density: } \\
\hline All public affairs organizations & $1,936.1$ & 669.5 & 2,172 & 779 & 2,799 \\
\hline Peace $\ldots \ldots \ldots \ldots \ldots \ldots \ldots \ldots$ & 120.8 & 49.4 & 104 & 58 & 197 \\
\hline Women's & 98.5 & 43.1 & 116 & 17 & 147 \\
\hline Human rights & 56.1 & 26.9 & 73 & 15 & 87 \\
\hline \multicolumn{6}{|l|}{ Government attention: } \\
\hline \multicolumn{6}{|l|}{ Total hearings (three-year moving } \\
\hline Peace hearings $\ldots \ldots \ldots \ldots \ldots \ldots \ldots$ & 5.4 & 3.7 & 4 & 1 & 15 \\
\hline Women's hearings $\ldots \ldots \ldots \ldots \ldots \ldots \ldots \ldots$ & 5.6 & 4.8 & 5 & 0 & 20 \\
\hline Human rights hearings $\ldots . . .$. . & 9.7 & 6.7 & 11 & 0 & 21 \\
\hline \multicolumn{6}{|l|}{ Resource environment: } \\
\hline \multicolumn{5}{|l|}{ Federal transfer funds (1997 dollars, bil- } & 223 \\
\hline \multicolumn{6}{|l|}{ Aggregate disposable income (1997 dollars, } \\
\hline \multicolumn{6}{|l|}{ Media attention: } \\
\hline Peace articles & 9.7 & 8.2 & 7 & 2 & 31 \\
\hline Women's articles ....... & 1.6 & 1.5 & 1 & 0 & 7 \\
\hline Human rights articles & 2.5 & 2.0 & 2 & 0 & 8 \\
\hline
\end{tabular}

NoTE.-The above estimates summarize annual values for the years 1965-97 for all dependent measures and the years 1964-96 for all independent measures $(N=33)$.

tions) or human rights (around 56 organizations). However, the majority of organizations engaged in public affairs fall outside these issue areas, as these three issue populations combine to constitute only $14.2 \%$ of the groups in the public affairs population in a given year; this is due to the quite diverse array of issue domains represented in the public affairs data.

Figures 2, 3, and 4 provide information about the density of membership and NMAO organizations within the three advocacy fields we investigate. In each, the primary y-axis displays the count of membership organiza- 


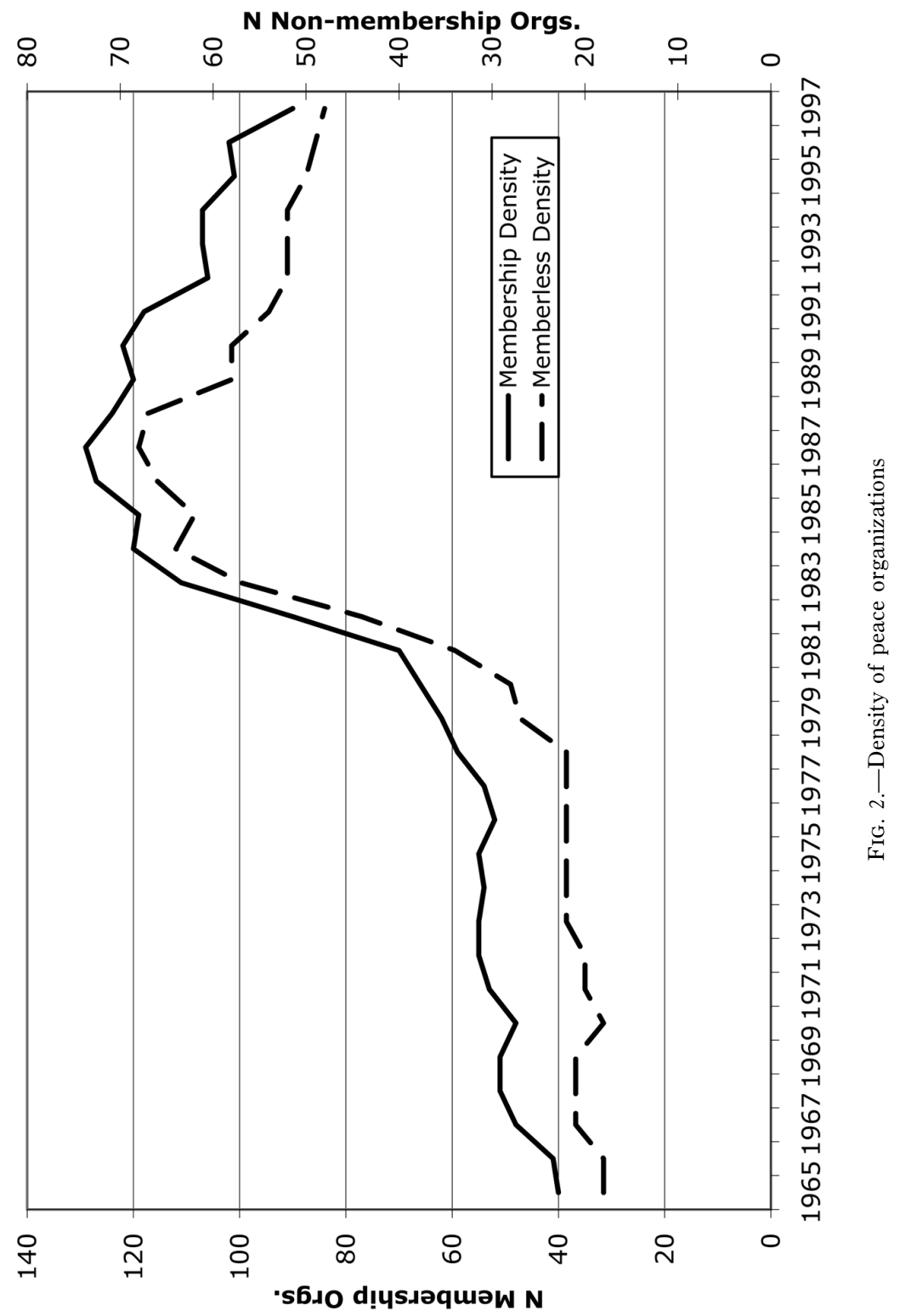




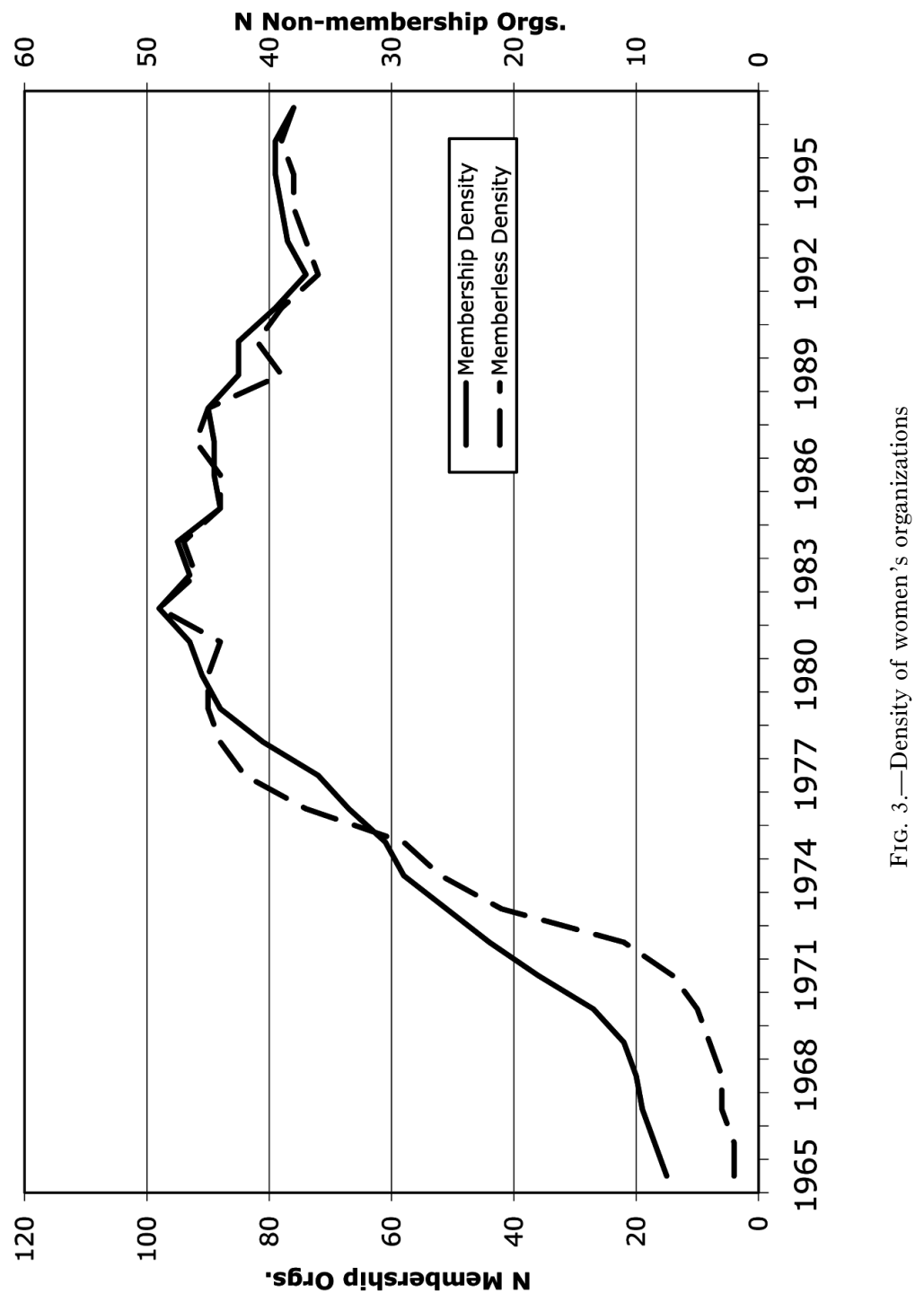




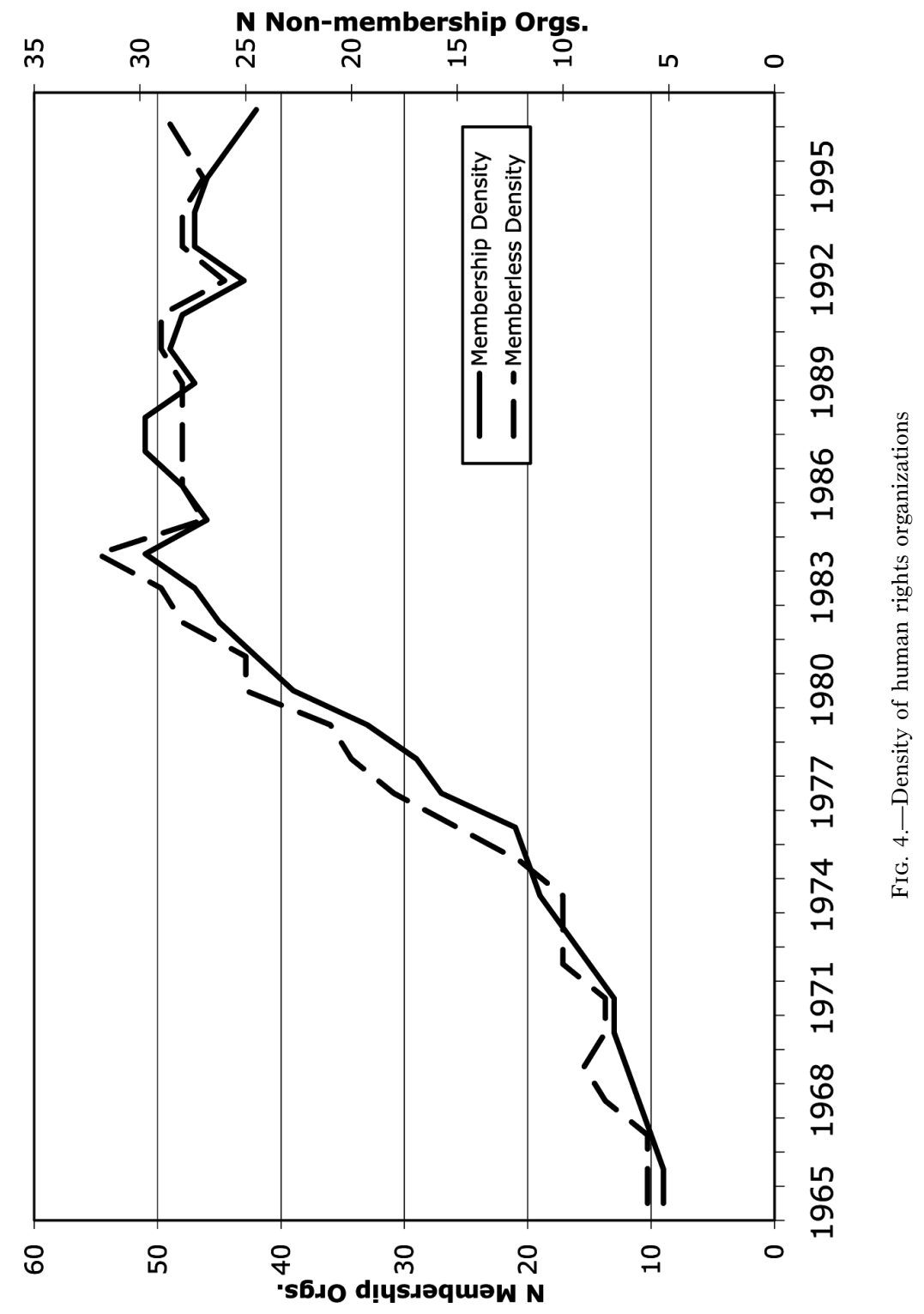


tions in the population, whereas the secondary y-axis displays the count of nonmembership organizations. Strikingly, these figures show that the patterns of organizational density in each of these three fields are nearly identical for both membership and nonmembership organizations, thereby providing support for hypotheses $1 b, 1 c$, and $1 d$.

Figure 5 shows the founding patterns of organizations in peace, women's, and human rights issues, as well as comparable figures for the entire field of public affairs organizations. For this figure, the right-hand axis is scaled for the entire field of public affairs organizations (this includes all three of these advocacy populations as well as all other organizations in the broader field), and the left-hand axis indexes organizational founding within the three issue domains. Figure 5 illustrates the patterns of organizational founding that shape, in part, the density counts displayed in figures 2-4. Most prominently, this figure indicates that the advocacy explosion of the late 1970s and early 1980s (Walker 1991; Berry 1997) was not confined to general organizations engaged in public affairs since all three advocacy populations in question saw significant growth during that period. Women's organizations grew steadily in the era surrounding the Roe decision and expanded again in the early 1980s; the founding of peace groups skyrocketed just before and after the inauguration of Ronald Reagan; human rights organizational growth followed after the implementation of the International Covenant on Civil and Political Rights by the United Nations in 1976.

As well, we see that all three populations follow a somewhat similar founding pattern when compared to the overall population of public affairs organizations: steady growth as the total organizational field expands in the late 1970s, then a peak period followed by a decline or plateau in density. Such an inverted-U-shaped curve has been found in a diverse array of organizational populations, from labor unions (e.g., Hannan and Freeman 1987), to microbreweries (Carroll and Swaminathan 2000), to low-powered FM radio stations (Greve, Pozner, and Rao 2006). We therefore find descriptive evidence that a process of density-dependent legitimation is at work in all three of these populations, as well as in the broader population of public affairs associations. However, the timing of the transition from expansion to contraction varies in each issue area: around 1987 for peace, 1993 for human rights, and 1989 for women's issues (although the decline in women's organizations is the most subtle). The degree of contraction appears to be greatest in the peace movement, which saw a 39\% decrease in population density between 1989 and 1998. Following the end of the Cold War, the movement also faced a period of sharp increases in organizational mortality (Edwards and Marullo 1995). 


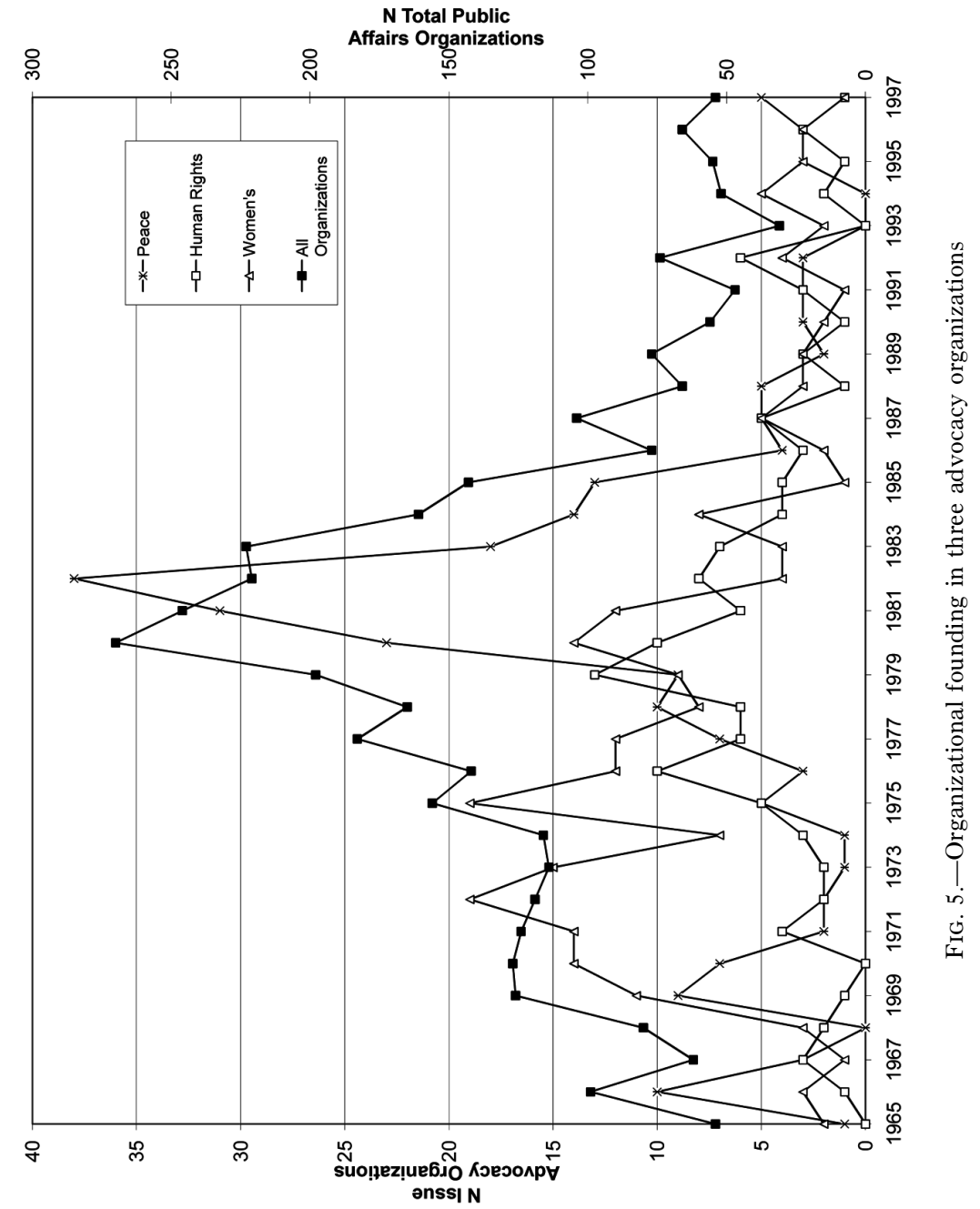


Analysis

Our goal in the subsequent analyses is a modest one. Our analyses provide the opportunity to assess the accuracy of our theoretical expectations about the cross-density effects of membership and nonmembership groups on their respective founding rates. We begin by presenting results from a series of regression analyses of the founding of all organizations engaged in public affairs from 1965 to 1997 . Most important, we seek to examine what differences might exist in the factors that shape the founding of these two organizational populations. In order to do this, we carry out a series of generalized linear models (GLM) that specify a Poisson distribution and Newey-West heteroscedasticity- and autocorrelation-consistent variance estimates. A Poisson distribution is appropriate for these dependent measures, which are event counts that are not overdispersed.

The coefficients presented in table 2 illustrate the strikingly consistent dynamics of how organizational populations shape the founding of public affairs associations, regardless of the type of association under consideration. Here we find support for the notion that the early stages of growth in the associational population under study are supported by the legitimation of the field, whereas in later years the dynamics of interorganizational competition become more prevalent (Hannan and Freeman 1989; Hannan and Carroll 1992). These findings provide further support for hypothesis $1 a$ in that both populations follow a nearly identical founding pattern. As well, comparing the density coefficients in columns 2 and 3 of table 2, it is clear that this pattern does not vary in any significant way on the basis of whether or not an NMAO engages in government advocacy, likely because-like membership associations-many such groups do not engage in formal government advocacy. This suggests that nonmembership and membership organizations serve complementary functions rather than representing contending associational forms. The only noteworthy difference between these three founding analyses is that the presence of government resources does not support the founding of memberless advocacy organizations, but their presence does significantly increase the founding rate for the entire public affairs population. Mean disposable income, surprisingly, has a significant negative effect on all three public affairs founding patterns, as disposable income rose steadily throughout the late 1960s as well as the 1990s; during both periods the founding of public affairs organizations was relatively low, and we understand these effects to be largely period based.

Having demonstrated that little difference exists in the factors that shape membership and NMAOs in the total field of public affairs organizations, we now consider the particular dynamics associated with each of the three domains in question: peace, women's, and human rights. 
TABLE 2

Poisson GLM Regression of the Founding of Public Affairs Organizations on Total Organizational Density, Government Attention, and Resources

\begin{tabular}{|c|c|c|c|}
\hline & $\begin{array}{c}\text { All } \\
\text { Organizations }\end{array}$ & $\begin{array}{l}\text { Nonmembership } \\
\text { Organizations }\end{array}$ & $\begin{array}{c}\text { Nonmembership } \\
\text { Government } \\
\text { Advocacy } \\
\text { Organizations }\end{array}$ \\
\hline \multicolumn{4}{|l|}{ Total organizational density: } \\
\hline $\begin{array}{l}\text { All public affairs organiza- } \\
\text { tions (hundreds of organiza- } \\
\text { tions) }\end{array}$ & $.529 * * *$ & $.530 * * *$ & $.499 * * *$ \\
\hline $\begin{array}{c}\text { All public affairs organiza- } \\
\text { tions }^{2}\end{array}$ & $-.011 * * *$ & $-.011 * * *$ & $-.010 * *$ \\
\hline Government attention: & & & \\
\hline Total congressional hearings & .000 & .000 & .001 \\
\hline $\begin{array}{l}\text { Resource environment: } \\
\text { Federal transfer funds (1997 }\end{array}$ & & & \\
\hline $\begin{array}{l}\text { dollars) } \ldots \ldots \ldots \ldots \ldots \ldots \ldots \\
\text { Aggregate disposable income }\end{array}$ & $.004 * *$ & $.005^{*}$ & .001 \\
\hline (1997 dollars) .............. & $-.001 * * *$ & $-.001 * * *$ & $-.001 * * *$ \\
\hline Constant $\ldots \ldots \ldots \ldots \ldots \ldots \ldots$ & $3.816^{* * *}$ & $2.952 * * *$ & $1.844^{*}$ \\
\hline Log likelihood $\ldots \ldots \ldots \ldots \ldots \ldots$ & -166.92 & -118.00 & -102.78 \\
\hline Observations ... & 33 & 33 & 33 \\
\hline
\end{tabular}

NotE.-Calculated using Newey-West heteroscedasticity- and autocorrelation-consistent variance estimates.

$$
\begin{aligned}
& { }^{+} P \leq .10 . \\
& * P \leq .05 . \\
& { }^{* *} P \leq .01 . \\
& \text { *** } P \leq .001 .
\end{aligned}
$$

Table 3 presents the results from GLM regression analyses of membership and NMAO founding within each of the latter organizational populations. For each of these models, we regress the founding measures on their issuespecific measures of organizational density, government attention, and media coverage, as well as the two measures of the resource environment.

First and foremost, the results in table 3 provide strong evidence in favor of the argument that membership organizations and NMAOs are shaped by similar external factors, most predominantly those of organizational density. As in the case of public affairs associations in general, all three associational fields-peace, women's, and human rights organizations-show strong effects of positive density dependence for both organizational forms.

More important for our purposes, we find, with one minor exception, that NMAOs have not displaced membership organizations (thereby providing support for hypothesis $2 a$ ). For peace and human rights organizations, in fact, we find that NMAO density actually helps to increase the founding of membership organizations. It is only in the case of 


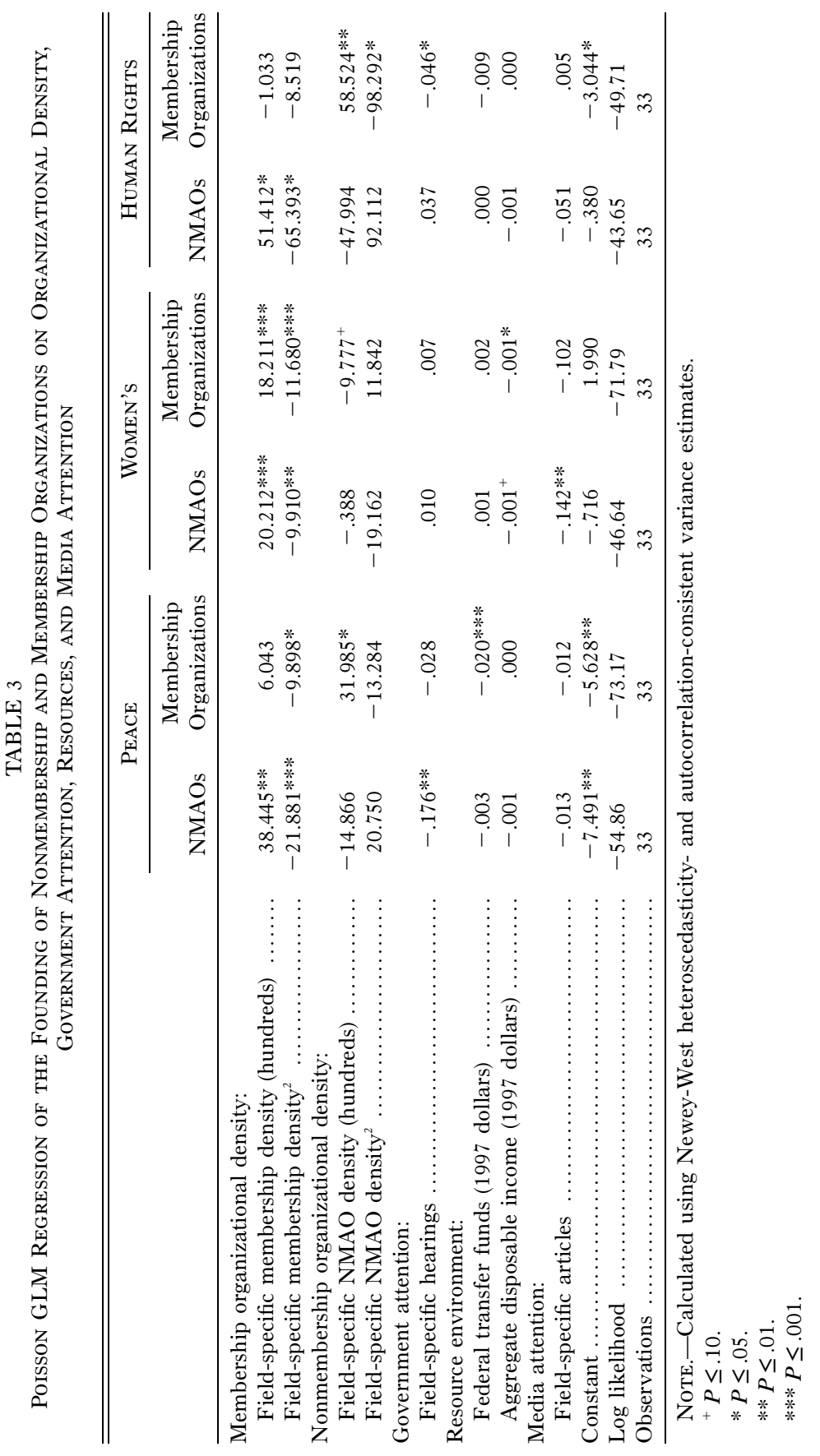


women's organizations that we find slight evidence of a competitive replacement effect in the negative and slightly significant $(P<.10)$ coefficient for women's NMAO density; we attribute this finding to the exclusion of women from many professions, especially prior to 1978. For instance, women's exclusion from the legal profession in the mid-20th century is well documented (Abel 1986; Hagan et al. 1991)—women represented $2.8 \%$ of all lawyers in 1970 , compared to more than $10 \%$ by the mid-1980s (Curran 1986, p. 25) - and may have posed a barrier to engagement in legal advocacy NMAOs. Similarly, women's exclusion from public office-consider, for instance, that the number of women in Congress more than doubled between 1969 and 1981 (Center for American Women and Politics 2010) - may have made the NMAO form less appealing to women's issue advocates, since this type of professional advocacy is more likely to rely on elite ties, and a lack of women in elected office is associated with less attention to women's issues (Thomas 1991). Despite divergence prior to 1978 , we find that after that point, women's membership and nonmembership organizations move largely in tandem. ${ }^{20}$

However, how does the density of membership organizations influence the founding of NMAOs? Although different from our assessment of the replacement hypothesis (in which membership organizations are displaced by the growth of NMAOs), the results here show that membership organizational density has strong positive effects on the founding of nonmembership organizations in all three fields (supporting hypothesis $2 b$ ). Indeed, in all three cases, the founding of NMAOs was influenced more by the density of membership organizations than by the density of other NMAOs. As we describe later, this particular finding fits well with evidence from public affairs associations engaged in a number of issues, from community organizing to women's advocacy. Most of all, what stands out here is the finding that membership organizations provide a strong foundation on which NMAOs build.

We find few significant effects of the other control measures in the analyses, although certain findings are worthy of further attention. First,

\footnotetext{
${ }^{20}$ In fact, in additional analyses (not shown), we found that this effect is nonsignificant in 1978 and after but highly significant for 1977 and earlier. This finding, importantly, accords with accounts of the women's movement during that period (e.g., Freeman 1973), which note that professionalized organizations played an increasingly dominant role in the movement in the late 1960s and early 1970s, especially following the establishment of President Kennedy's Commission on the Status of Women in 1961; this brought together professional women at both the state and the federal levels in order to research limitations to equal opportunity and encouraged further organizing by women. Similarly, the addition of Title VII to the 1964 Civil Rights Act showed government support for equal opportunity measures but was only partially enforced; this encouraged greater organizing by professional women, many of whom became active in government, lobbying, and legal advocacy.
} 
government hearings related to the concerns of a given advocacy field occasionally decrease the founding of new organizations; we find this pattern among peace NMAOs and human rights membership organizations. We take this as preliminary evidence that government action discourages those who would found new organizations from taking action in the very short term. Second, we find relatively little influence of our resource measures, since neither transfer funds nor greater disposable income shaped founding patterns in most cases. Federal transfer funds increased dramatically the end of the Cold War, which helps to explain the negative effect of transfer dollars on the founding of peace membership organizations. Similarly, much of the advocacy on women's issues took place during a period of relatively flat growth in disposable incomes. Finally, media attention to an issue has, in general, little effect on founding events, although less media attention is associated with significantly more women's NMAOs founded in the following year. We expect that this finding derives from the increased media attention to women's issues that such NMAOs often generate; attention to women's issues was lower prior to the expansion of this field.

Overall, then, our findings indicate that nonmembership and memberbased organizations are, by and large, mutually supportive rather than competitive. In addition, these findings are consistent even when controls for the political, resource, and media environments are entered into the model.

\section{NMAOS AS SERVICE PROVIDERS TO THE MEMBERSHIP ORGANIZATION COMMUNITY}

What are the mechanisms by which membership and nonmembership organizations in the same field find mutual benefit? Evidence suggests that the founders of NMAOs are often inspired to achieve many of the same goals as the leaders of membership organizations but prefer to put their professional and technical skills to different uses. ${ }^{21}$ Further, NMAOs

\footnotetext{
${ }^{21}$ Consider, e.g., how the website of the Southern Poverty Law Center describes its cofounder Morris Dees: "In 1967, [he] had achieved extraordinary business and financial success with his book publishing company. The son of an Alabama farmer, he witnessed firsthand the painful consequences of prejudice and racial injustice. $\mathrm{He}$ sympathized with the Civil Rights Movement but had not become actively involved. A night of soul searching at a snowed-in Cincinnati airport changed his life, inspiring Dees to leave his safe, business-as-usual world and undertake a new mission. 'I had made up my mind. I would sell the company as soon as possible and specialize in civil rights law,' Dees said. 'All the things in my life that had brought me to this point, all the pulls and tugs of my conscience, found a singular peace. It did not matter what my neighbors would think, or the judges, the bankers, or even my relatives'” (Southern Poverty Law Center 2008).
} 
often help to conduct research, provide institutional linkages to policy makers, and help membership organizations get their message out in the media. ${ }^{22}$ More directly, we discuss here five examples of the types of tight and supportive links that characterize this macro-organizational division of labor. In particular, we focus on organizational activities common among nonmembership organizations that appear to have as their main purpose the goal of enhancing the fortunes of membership-based groups within the same field. For representative examples of the membership and NMAO organizations that constitute our data, see appendix table A1.

Recall that we earlier identified Washington advocates as the most widely recognized type of nonmembership organization. We now briefly explore the wide diversity among NMAOs beyond Washington advocates, calling attention to the diversity of activities, goals, and organizational linkages among NMAOs active in public affairs. In discussing this variation, we note the often complementary role of nonmembership organizations to organizations that engage members more directly in organizational activity.

One of the most central organizations in modern antipoverty organizing, interestingly, is an association without members. The Industrial Areas Foundation (IAF) was founded by Saul Alinsky in 1939, following from the community organizing efforts of the Back of the Yards neighborhood of Chicago (Reitzes and Reitzes 1987; Horwitt 1989). Although the organization was founded as an institutionally based grassroots community organization, the IAF restructured in the mid-1970s to be a national network of affiliated interfaith community groups engaged in efforts to provide voice to low- and moderate-income regions of the country (Warren 2001). As such, the main task of the IAF is to assist in the creation and maintenance of local community organizations, which in turn voice the concerns of those communities on issues such as job opportunities, school quality, health, housing, and urban blight (Osterman 2002). We refer to the IAF, and similar organizations such as PICO (previously the Pacific Institute for Community Organization, now called People Improving Communities through Organizing) and the Center for Third World Organizing, as belonging to the membership organization network type; as such, although they are staff-driven organizations, their primary purpose is supporting face-to-face civic engagement and community organizing.

\footnotetext{
${ }^{22}$ For example, Freeman (1973, p. 801) makes reference to an interaction between radical feminist organizers and the nonmembership Center for Policy Studies (CPS), in that their "1968 conference was organized by the Washington, D.C. group from resources provided by [CPS], a radical research organization. Using CPS facilities, this group subsequently became a main literature-distribution center."
} 
Importantly, there is evidence to suggest that NMAOs of this type may be more effective in building civic infrastructure than federated membership organizations (Minkoff et al. 2008, p. 542). ${ }^{23}$

Similarly, the Center for Community Change, established in 1968, is an NMAO that works to strengthen and build the voice of low-income community advocates. Its mission is to amplify the voice of local community organizations (especially in national-level policy debates); bring together community organizations across race, issue, and location; and "build the social movements of tomorrow" by organizing leadership development conferences. ${ }^{24}$ Like the IAF, this network supports and complements the activities of grassroots membership organizations.

Beyond Washington advocates and membership organization networks, a third type includes think tanks, policy planning organizations, and other research organizations that seek to shape public discourse and policy making within an issue area (Peschek 1987; Rich 2004). Our shorthand for this type of NMAO is policy planning organization. These organizations span the political spectrum, and many have come to play a quite significant role in the creation and implementation of public policy since the early 1970s. Perhaps the most prominent of these organizations are the conservative Heritage Foundation and American Enterprise Institute, the libertarian Cato Institute, and the centrist Brookings Institution. Although these organizations have staked claims in support of a somewhat diverse array of political ideologies, a number of analysts have associated their appearance with a broader rightward turn in American politics (Himmelstein 1990). For example, the Family Research Council, an offshoot of Focus on the Family that was headed by former Reagan adviser Gary Bauer, was influential in shaping congressional dialogue regarding trade policy with China and other countries perceived to be active in restricting the religious freedoms of Christians (Martin 1999). Although organizations that devote time and effort to informing, educating, and communicating with members may, at times, preclude successful advocacy on fast-moving matters of policy creation and reform, there is a productive division of labor between policy planning organizations and grassroots membership organizations. Grassroots associations often lack policy expertise, but policy planning groups may lack the authenticity of local citizens' organizations. ${ }^{25}$

${ }^{23}$ Further, and consistent with our findings, Minkoff et al. (2008, p. 544) contend that the "[nonmember] network model . . . plays a critical role in the sector despite its reliance on other organizations as opposed to direct citizen involvement."

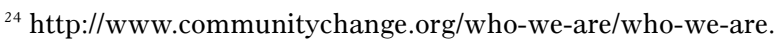

${ }^{25}$ Well-heeled organizations often engage in professional public affairs campaigns in order to bridge the gap between these two sources of legitimacy (Walker 2009). 
Quite distinct from such professional organizations engaged in elite policy dialogue are those that avoid direct government advocacy in favor of indirect social advocacy and engage only in service provision to a constituency, which we refer to as service providers. One example of such a group is the American Woman's Economic Development Corporation, which was founded in 1976 as an educational organization that provides training and technical assistance to women seeking to own a business. Similarly, a variety of service-providing NMAOs provide nonprofit legal services; an example of this is the Center for Constitutional Rights, which provides legal services to poor and minority communities and assists in legal battles related to human and civil rights. As such, this organization walks the line between advocacy and service provision (on this issue, see Minkoff [1994]). Such professional social service agencies have benefited from the increased government reliance on organizations in the voluntary sector to provide community programs in place of government (Heclo 1978; Skocpol et al. 2005); importantly, many such programs rely on grassroots support for their survival despite their staff-driven nature.

Some of the most crucial NMAOs active in advocacy are what we refer to as ancillary organizations: those groups that engage directly in providing the informational, legal, educational, lobbying, and/or constituentbased support often necessary to support the activism of a small number of movement organizations. Perhaps the quintessential example of such an organization is the NAACP Legal Defense and Education Fund. Another such NMAO is an organization referred to as the People's Project (Fisher 2006), which employs staff to carry out paid canvassing campaigns to build the membership and donor bases of organizations such as the Sierra Club, the Public Interest Research Groups, and Save the Children. Again, the tie between membership groups and professional advocates is apparent.

Foundations are a final type of NMAO; these support social movement and interest group activism through grants and in-kind contributions (see Walker 1991; Prewitt 2006). While known for their support of more moderate and professional types of movement organizations (Jenkins and Halcli 1999), foundations often play a strong role in advocacy populations by providing resources to other organizations and by publicizing the policy victories of the groups to which they are sympathetic. Foundation funding is also associated with increases in longevity for the membership organizations they support, although relying on any one source of income too heavily is often a liability for the recipient group (Cress and Snow 1996). 


\section{AN ADDITIONAL NOTE ON CHANGE WITHIN MEMBERSHIP AND NONMEMBERSHIP ASSOCIATIONS}

At the outset of our discussion above, we noted that our analysis would be limited primarily to the interorganizational dynamics of the two organizational forms in question and that we would not systematically evaluate the notion that membership organizations themselves have changed from federated organizations that provide members with thick network ties, social capital, and political skills to those that represent distant centralized offices that rely on membership lists and mass-distributed "action alerts." A key implication of the arguments of Skocpol (2003) is that regardless of the increasing prevalence and significance of NMAOs, membership organizations themselves have undergone a significant transformation away from meaningful member participation in their own right. As such, the line between "member" and "supporter" is increasingly blurry (Bosso 2003). It may also be the case that nonmember associations have undergone significant change in this direction, relying more heavily on technologically driven grassroots lobbying techniques such as mass e-mail mobilization rather than more direct activities of their staff (such as direct legislative lobbying, legal advocacy, community-based fund-raising, and the like).

Although not central to our study-our data do not allow for a rigorous evaluation of these claims-one approach to indirectly approximating whether such a change has, in fact, taken place is to examine structural changes in the organizational chapter structure within each type. We do so by estimating whether associations report having any regional, state, or local chapters (for a similar analysis using founding rather than density data from the 1995 edition of the Encyclopedia, see McCarthy [2005, pp. 203-6]). To the extent that organizations today are less likely to have chapters-regardless of whether they have members in those chapters or instead populate their chapters with staff only, as in organizations such as Earthjustice Legal Defense Fund-this provides some indirect indication as to whether associations have transformed in the direction of increasing centralized "management." Our measure of associational location tracks the proportional density of organizations residing in Washington, D.C.

The findings presented in figure 6 illustrate that among membership associations, there has not been a dramatic increase in organizations with headquarters in the nation's capital, with a slight but steady decline since the mid-1980s. And, despite expectations of a decline in federated organizations, we see a dramatic increase in the proportional density of organizations with any chapters; for example, while in 1974 only around $21 \%$ of membership organizations had any regional, state, or local-level 


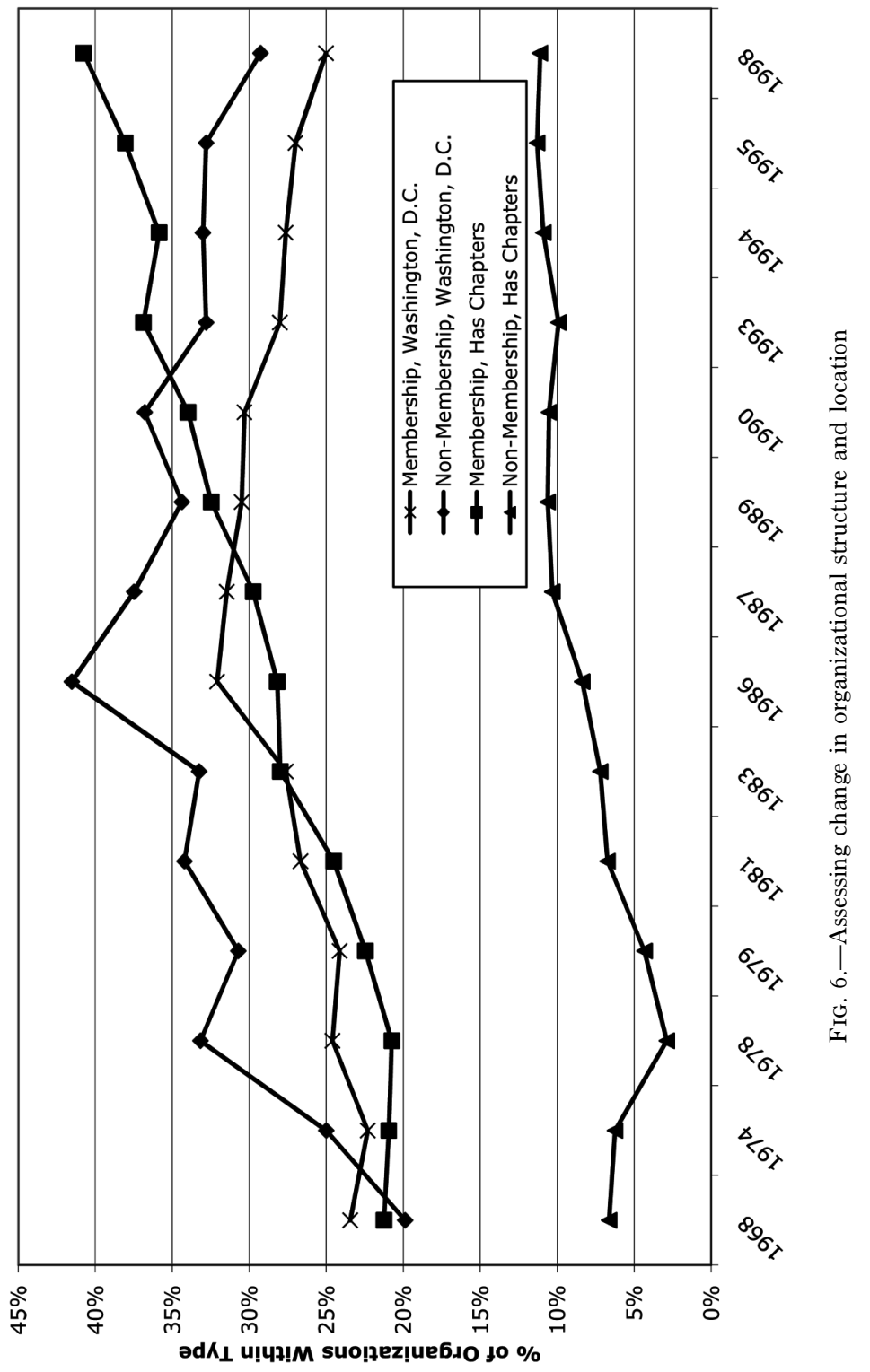


chapters, by 1998 that figure had increased to over 40\%. This squares with Shaiko's (1999, p. 11) finding that a key growth strategy for mature advocacy organizations in the 1980s and 1990s was to establish new chapters or branch offices. An important additional finding shows that the number of membership associations based in Washington, D.C., increased between 1968 and 1986 but declined between 1986 and 1998. ${ }^{26}$ In sum, then, this evidence suggests that there has not been a significant turn toward centralized Washington advocacy among membership organizations active in public affairs. ${ }^{27}$

Have NMAOs, for their part, seen a decline in chapters and an increase in their likelihood of opening operations in Washington? As figure 6 also illustrates, the 1968-86 period also saw a significant increase in Washington offices for NMAOs and a much steeper one than for membership groups, as nearly $43 \%$ of such associations were located within the Beltway by the late 1980s; this figure declined and then maintained a plateau at around $33 \%$ thereafter. A comparatively far smaller proportion of NMAOs have regional, state, or local chapters, but the proportion that do increased gradually, nearly doubling, between the late 1960s and the late 1990s. Thus, while NMAOs are quite a bit more likely to be located in Washington, they are also more likely today to have chapters than they were in the 1970s. Importantly, those NMAOs that have chapters, evidence suggests, are especially adept at supporting the civic infrastructure needed to mobilize participants (Minkoff et al. 2008).

\section{CONCLUSIONS}

The evidence we have assembled demonstrates unequivocally that while the NMAO form among public affairs associations has seen a dramatic increase in number in the period 1965-97, we also know that the proportion of such organizations has remained nearly constant over the same time period. Consequently, despite the many strong claims that the national advocacy field has made a transition from "membership to management" (Skocpol 2003), we instead find strong reason to believe that the organizational field of public affairs associations is characterized

\footnotetext{
${ }^{26}$ This may be due, in part, to many new advocacy organizations deciding to open operations in the Virginia or Maryland suburbs of Washington.

${ }^{27}$ We remain open, as out the outset, to the notion that the qualitative meaning of membership in both federated and nonfederated organizations has undergone significant changes; there is much to suggest that civic organizational membership has come to represent something more akin to "affiliation" rather than fully engaged participation. As Putnam (1995, p. 71)—perhaps too strongly—puts it, members today "root for the same team and they share some of the same interests" but may be "unaware of each other's existence."
} 
mainly by stability in the relative proportions of the membership and nonmembership organizations that it comprises. More directly, we find little evidence to support the position that membership organizations are being displaced by a highly professionalized set of institutional advocates; we instead find evidence of a mutually supportive relationship.

What our analyses show, most significantly, is that membership organizations did not decline alongside the increasing number of professional staff-only associations engaged in public affairs; instead, both of these populations grew dramatically during the major period of interest group growth in the late 1970s and early 1980s. And, rather than displacing membership groups, these two populations grew at a roughly proportional rate. Our statistical analyses illustrate this finding even further by showing that the density of memberless associations had a positive and significant influence on the founding of membership organizations among peace and human rights organizations; conversely, the density of membership organizations also had a positive and significant influence on the founding of NMAOs in all three fields under examination.

An important implication of these findings is that the post-1960s era has involved a consistent division of labor between member-driven and professional advocacy, both among advocacy organizations as a whole and within particular issue domains on the left of the political spectrum. Modern advocacy organizations, then, appear to face a number of environmental pressures that help to channel sets of organizations into these consistent complementary roles, in that (1) media and political environments require both evidence of popular support and expert knowledge, (2) issues tend to be incredibly complex and require professional knowledge in order to make sense of them (Lippmann 1966; Brint 1996), and (3) effective issue advocacy both requires audience acceptance on the pragmatic grounds of being able to provide useful information (cf. Hall and Deardorff 2006) and at the same time has the moral legitimacy of accurately representing citizens' views in a pluralist democracy. ${ }^{28}$ While the environments within which organizations are embedded have evolved in the direction of increasing complexity and greater requirements for transparency, the requirement that advocates both mobilize mass participation and utilize the specialized expertise of professionals remains in place, even if the means of doing so have changed significantly with the development of new information and communications technologies.

Regarding the question of whether citizen advocacy has expanded without an accompanying expansion of civic engagement, our findings suggest that even though the replacement hypothesis did not find support, it remains plausible — as we suggested earlier— that the meaning of "mem-

\footnotetext{
${ }^{28}$ See Suchman (1995) for a comprehensive discussion of organizational legitimacy.
} 
bership" has evolved in those organizations that have members. A limitation of our analysis is that it effectively brackets the question of change in the qualitative meaning of "membership" in those organizations that claim them. Analysts have claimed that the supply side of participatory opportunities for individual engagement has decreased because the newly founded organizations of the "interest group explosion" (Walker 1991; Berry 1997) do less to engage their members in face-to-face activity, operating instead as "centralized and professionally led organizations focused on policy lobbying and public education" (Skocpol 1999b, p. 68). Even though figure 6 suggests that membership organizations are more likely to have chapters today, membership organizations founded in more recent decades are likely to spawn fewer local chapters than older organizations (McCarthy 2005); moreover, groups that have regional, state, or local chapters may no longer be as effective in producing the thick face-to-face ties that older federated organizations once did (Skocpol 2003). Thus, while our research indicates that the decline of civic engagement and growth of professional advocacy do not appear to be outcomes of the growth of NMAOs, it remains possible-even likely—that "membership" does not carry quite the same meaning it once did. However, we also find evidence that NMAOs often provide significant support for civic engagement and appear to enhance rather than detract from civic infrastructure. Future research should investigate the extent to which staffdriven organizations support civic engagement, whether through incentivizing public participation or assisting membership organizations. In addition, we encourage researchers to explore which types of interactions are most common among these two organizational types, such that the emergence of this macro-organizational division of labor in public advocacy can be understood in fuller detail.

We believe that our findings also have implications for scholars interested in the changing means by which organizations connect "people to politics" (Weir and Ganz 1997; Skocpol 2003; Walker 2009; Andrews et al. 2010). Weir and Ganz (1997), for instance, have argued that the changing structure of civic organization in American society in the closing decades of the 20th century has meant quite different things for organizations on the political right and left, since organizations on the right have been more effective at building on the existing networks and infrastructures of religious, recreational, and social ties, whereas progressive organizations have focused more heavily on single-issue advocacy through lobbying and legal tactics (see also Fisher 2006). Although they believe that progressive organizations such as the Industrial Areas Foundation, described earlier, represent an exception, Weir and Ganz contend that even groups like these "have not been able to connect local organizing activities to broader political or policy goals" (p. 162). While our data and findings cannot 
speak directly to the comparative effectiveness of organizations on the right and left in influencing policy, an implication of this study is that the relatively constant presence of nonmembership associations in the advocacy field may not be quite the culprit of recent changes in civic capacity that they have been made out to be. Despite the expectation that organizations on the left of the political spectrum have been more heavily affected by the rise of professional advocacy, we have provided evidence that in three left-leaning organizational populations, there has been little proportional increase in this staff-driven organizational form.

It is important to note, as we earlier mentioned, that associations without members are often created in order to support the activities of membership organizations and build civic engagement; this argument is supported by our finding that nearly half of all NMAOs do not engage in formal government advocacy and therefore do not fit the profile of a Washington advocate organization. Further, at no point during our time series did we find that more than $50 \%$ of all NMAOs were located in Washington, D.C. The legal defense funds, educational programs, lobbying organizations, and project committees that constitute a sizable portion of the population of NMAOs are, in fact, often created in order to provide the technical and professional services that membership organizations need in order to advocate their cause within political, media, legal, and other institutions. Many nonmembership organizations, such as the restructured Industrial Areas Foundation (Warren 2001; Osterman 2002) and the National Congress of Neighborhood Women, lack "members" but are devoted to assisting the start-up and maintenance of grassroots community organizations. As well, the growth of membership organizations appears to create an increased demand for the services and support that staff-only institutes, centers, and funds often provide to activist groups. However, we also find the curvilinear effect of interorganizational competition present in all of our models (in both the standard and cross-density models), suggesting that once each population reaches its carrying capacity, both membership organizations and professional advocates compete over the same resources and support in the environment (on this dynamic, see Singh and Lumsden [1990]). An important footnote to our analyses, then, is that the mutualism that exists between these two organizational forms entails both the benefits of mutual legitimation and the costs of sharing scarce resources within a population of advocacy groups. 


\section{APPENDIX}

Data Sources and Measures

Encyclopedia of Associations

Our data are drawn from the Encyclopedia of Associations, a directory of associations published on a regular basis by Thomson/Gale (previously Gale Research) since 1956. The data used in this paper were extracted from the public affairs section of the Encyclopedia. ${ }^{29}$ Our analyses here focus on all groups included in the public affairs section as a whole as well as those in three particular organizational fields that are almost fully contained within the public affairs section: peace, women's, and human rights advocacy groups. Some potentially interesting advocacy organizational fields, such as those associated with the environment or civil rights, are much less fully contained within the public affairs section, so we do not analyze them here.

There are, of course, important concerns regarding bias of inclusion and comprehensiveness of inclusion in the Encyclopedia, and our data are only as complete as the source from which they are drawn. It is difficult to assess the completeness of coverage of a directory such as the Encyclopedia, which has consistently sought to include a record for every national-level association in America. Of course it cannot be complete. But how complete is it, and what is the nature of any bias of inclusion? This question has been assessed in a systematic manner for the case of labor unions included in the Encyclopedia on the basis of information available because all unions are required to register with the U.S. Department of Labor. Martin, Baumgartner, and McCarthy (2006, pp. 77172) found that $76 \%$ of the unions registered with the Labor Department were listed in the Encyclopedia and that coverage for unions above 5,000 and 10,000 members was $91 \%$ and $95 \%$, respectively. Similarly, financial heft was a significant predictor of inclusion: $89 \%$ of those with annual receipts greater than $\$ 1$ million were covered, compared to $51 \%$ of those with less than that amount. Geographical location (e.g., being based in the nation's capital) was not a significant correlate of coverage (p. 776). This is the only systematic comparison of the Encyclopedia coverage with a known population list of which we are aware, and it suggests that the compilers of the directory have done a very good job of locating large, substantial organizations active at the national level but that coverage of smaller, newer, or less substantial groups may be considerably lower. We suspect that this pattern is replicated across other categories of national associations (see also Minkoff 1995, p.132).

${ }^{29}$ There are 16 total sections of the Encyclopedia. 
Questions may also be raised about the criteria for inclusion used by the Encyclopedia of Associations (especially with regard to the membership/nonmembership distinction) and whether its staff diligently, and consistently, worked to update entries through the years of its publication used in this research. We have read the introductory explanations for almost every annual volume of the Encyclopedia seeking answers to these questions. Two observations concerning that series of accounts are relevant to the current research. First, the early volumes aimed to be inclusive of "non-profit American organizations of national scope" (Ruffner et al. 1964, p. 7) and, by 1973, aimed explicitly to include nonmembership groups (Fisk 1973, p. 7); by 1978, and subsequently, the editors indicated that "for-profit and non-membership groups are included if their names or activities suggest that they are voluntary nonprofit organizations" (Pair 1978, pp. viii-ix). To the extent that the criteria for inclusion evolved during the period of our analyses, they made it increasingly likely that nonmembership groups were included in the Encyclopedia; however, this tendency would be expected to enhance any trend showing the increasing density of nonmembership groups included, rendering our test of the replacement hypothesis a conservative one.

Second, explanations of procedures described in each annual edition strongly suggest that Encyclopedia staff have actively updated entries and aggressively sought new organizations to be included even during its early years. By 1976, the editors "estimate that more than ninety percent of the previously listed organizations have made one or more changes in their listings for this edition" (Fisk 1976, p. viii). And, by 1981, the editors claim "that more than ninety percent of the previously listed organizations have made one or more changes in their listings for this edition. . . . This is about the same rate of change found in recent past editions. . . . 910 new entries, prepared from questionnaires completed by the organizations or from secondary sources, have been added to this edition" (Akey 1981, p. vii). And in 1996, the editors state that their objective "for each edition of [the Encyclopedia] is complete verification or updating of existing entries and the identification and description of new or previously unlisted organizations. This intensive effort includes several revision form mailings and direct contact by correspondence and telephone with non-responding groups. Groups constantly form, disband, relocate, or refocus their efforts, and the editors estimate that for this edition more than 500 associations have been added and 90 percent of the respondents reported some change to their description" (Jaszczack 1996, p. ix). These several explanations point to relative consistency in procedures over the period of our research. The Encyclopedia added a parallel online version (Associations Unlimited) well after 1997, the last year of our present analyses.

We have two rationales for using only the associations listed in the 
public affairs section of the print Encyclopedia for these analyses. The first is theoretical and the second purely practical. To begin with, the associations included in the public affairs section are, in general, much more germane to our current focus on national advocacy organizations than those included in any other section of the Encyclopedia. To be sure, many advocacy organizations are to be found in other sections, such as cultural organizations, educational organizations, religious organizations, and social welfare organizations. But the vast majority of advocacy organizations appear to be concentrated in the public affairs section.

Second, more practically, the data we use were generated as part of a larger project carried out by the second and third authors. ${ }^{30}$ It relies on information that was extracted concerning many aspects of the organizational structure of each group on a nearly annual basis, including the nature of membership, but only for the public affairs section. Generating that level of detail annually for this section proved to be incredibly labor intensive, and as a result, it proved infeasible, because of a lack of resources, to continue to do this for additional sections. As a result, however, for all the organizations listed in the public affairs section for the years we examine here, we have reliable estimates of membership type on an annual basis, providing the basis for the current analyses.

Since the detailed analyses that follow focus on three advocacy associational fields-peace, women's, and human rights—one might ask whether we can provide assurance that the national advocacy associations included in the Encyclopedia for these three fields are contained mainly in the public affairs section through the years. To address this question we first did a search of the 1995 digital record of the Encyclopedia (Gale Research 1995) using the keywords we used in generating our three advocacy associational fields for the present analyses. ${ }^{31}$ This electronic record of the 1995 edition of the Encyclopedia allowed us, then, to determine what proportion of listed associations were located in the public affairs section in 1995, a crude indicator of the year-to-year inclusiveness of

\footnotetext{
${ }^{30}$ As part of the Policy Agendas Project (http://www.policyagendas.org), they have been compiling a comprehensive database of the entire contents of successive editions of the Encyclopedia (one observation every five years) and coding each organization for the main policy focus of its activity. This database will allow comprehensive analyses of the growth and development of the organizational structure of American society and how this relates to various indicators of U.S. federal government activity also available through the policy agendas website. They expect to release the new Encyclopedia data set through the Policy Agendas website.

${ }^{31}$ For peace: peace, disarmament, nuclear war and weapons, draft, conscientious objectors, antidraft, war resistance, and youth against war; for human rights: amnesty, capital punishment, human rights, political prisoners, and refugees; and for women: feminism, reproductive rights, reproductive freedom, sexual harassment, woman, woman's rights, women, and women's rights.
} 
groups. For peace groups, more than $99 \%$ of the groups were included in the section; for human rights groups, more than $71 \%$ of the groups were included ${ }^{32}$ for women, a little more than $52 \%$ of the groups were included in the section. This initial assessment suggested that inclusion rates were acceptable for the peace and human rights advocacy fields but that we needed to look more deeply into which women's groups were excluded from the public affairs section and to assess the appropriateness of groups included and their comparability to populations of women's advocacy groups used in previous analyses of the field.

Those women's associations not included in the public affairs section, as captured by our string of keywords, are concentrated primarily in the sections of social welfare organizations (27), religious organizations (18), educational organizations (17), cultural organizations (11), and health and medical organizations (10). However, almost all of the associations (95 out of 98) captured by the keyword "feminism" are included in the public affairs section as are all of those captured by the keyword "reproductive rights." These patterns suggest that the majority of the associations that Minkoff, in her several analyses of women's associations, termed "advocacy organizations" are included in the public affairs section of the Encyclopedia. As well, and importantly, Minkoff's (1995, p. 59) basic data set includes 141 pure women's advocacy groups having existed sometime during her 1955-85 time series as well as 74 women's advocacy/service groups, whereas the data we analyze here show that a total of 248 women's groups (included in the public affairs section) existed at some point during our 1964-96 time series, with 119 of them showing evidence of efforts to influence government. This correspondence strongly suggests that restricting our analysis of women's advocacy groups to only those included in the public affairs section of the Encyclopedia does not, in any significant way, undermine their inclusiveness.

Finally, its should be noted that, in spite of the serious concerns we have addressed about the source's comprehensiveness and potential biases, the Encyclopedia of Associations is widely recognized as the most inclusive census of national nonprofit associations. As a result, it has been used widely by researchers of various segments as well as the entire national nonprofit organizational landscape, and much of what we know about that landscape depends on the source. We have compiled a list of more than 150 refereed journal articles that utilize information drawn

\footnotetext{
${ }^{32}$ If refugee issues are excluded, our coverage of human rights issues approaches $100 \%$; 26 of the 37 groups listed under the heading for "refugees" were considered social welfare rather than public affairs organizations.
} 
from one or more editions of the source. ${ }^{33}$ And, in many of those research reports, those knowledgeable about their own small segments of the associational world the source attempts to chronicle provide testimonials about its utility and comprehensiveness of coverage. ${ }^{34}$

\section{Control Variables}

The following discussion describes the measurement of the independent variables employed in the analyses presented in tables 1-3. Our measure of government attention also comes from the Policy Agendas Project (policyagendas.org) and uses annual estimates of the number of total congressional hearings on the issue in question. We constructed four measures of government activity. The first is a measure of overall government activity, which takes the three-year moving average of the total number of congressional hearings. We use three-year moving averages because nonelection years have significantly higher numbers of hearings than election years. The remaining three measures indicate the volume of congressional hearings related to each specific social issue domain: peace, women's, and human rights issues. Using the descriptions provided by the Congressional Information Service/Annual: Abstracts of Congressional Publications and Legislative History Citations, coders read the full text of the description of each hearing, sorting them into the issue areas of the Policy Agendas Project. ${ }^{35}$ Using the issue areas, we created yearly counts of hearings related to each issue domain. ${ }^{36}$ Congressional hearings are a useful in-

\footnotetext{
${ }^{33}$ An annotated bibliography of research articles employing the Encyclopedia of Associations in some manner is available from the authors by request.

${ }^{34}$ For example, a researcher of insurance-related trade associations attempted to generate a comprehensive list of such associations and testified, "In most cases the information in the Encyclopedia of Associations is more complete" (Dorfman 1973, p. 264); similarly, a systematic study of national self-help associations found that the Encyclopedia of Associations "consistently overlapped" with the leading field-based census of associations (Archibald 2007, p. 606).

${ }^{35}$ Hearings included are those of committees, subcommittees, task forces, panels and commissions, and the joint committees of Congress. Not all entries in the Congressional Information Service hearings section are actually hearings, and, as such, they are not included in this data set. Committee reports, publications, supplementary materials, and declassified material are examples of entries in the source that are excluded in the database.

${ }^{36}$ Peace hearings include those relating to protests of the Vietnam War, student unrest on university campuses (if there was any indication that it was related to war), and all direct war-related hearings: appropriations for military operations in Vietnam, U.S. relations with Laos, cost of the Vietnam War, impact of the Vietnam War, war-related civilian problems in Laos and Cambodia, air war against North Vietnam, Gulf of Tonkin incidents, U.S.-Laotian security relations, military strategy and other issues directly related to the Korean War, prisoners of war, Geneva convention for protection
} 
dicator of government attention since they have a relatively low threshold; thousands of hearings are held on hundreds of topics each year, and hearings correspond generally with other possible indicators such as bill introductions, laws, and presidential attention (see Jones and Baumgartner 2005).

The resource environment may also have significant influences on the structure and focus of an advocacy organization (Staggenborg 1988); we therefore include two lagged measures of the external resource environment as controls in our analyses. First, we include an inflation-adjusted measure of federal transfer funds to states and localities, as provided by the Office of Management and Budget. As the grants that the U.S. federal government provides to these lower levels of government are one of the central sources of public-sector support to many associations (Minkoff 1995), increased levels of federal support to localities should be associated with an increased rate of organizational founding. Second, we also include an inflation-adjusted indicator of the mean disposable income of U.S. residents, as reported by the Federal Reserve Bank and provided by the Statistical Abstract of the United States. We include this control mainly because of the criticism directed at nonmembership organizations for being highly dependent on check-writing conscience constituents and because evidence suggests that increased levels of disposable income may heighten individuals' level of donation to nonprofits (Havens, O'Herlihy, and Schervish 2006). ${ }^{37}$

of prisoners of war, shipment of war relief supplies, and war assets administration. Women's issue hearings include those regarding gender and sexual orientation discrimination, social security inequities affecting women, employment barriers to women, female salary inequities, sex discrimination regulations, equal pay for women, and all other issues related to the civil rights of women. Human rights hearings include such issues as human rights abuses in Latin America, human rights abuses in the Middle East, war crimes tribunal hearings for Serbs, U.S. international human rights policy, Helsinki Accords human rights agreements, UN report on human rights in Cuba, Soviet human rights issues, government use of torture, human rights violations in Indonesia, worldwide religious persecution, crimes associated with genocide, and crimes against humanity.

${ }^{37}$ Additional analyses (available on request) also included an additional resource variable as a control in our models of the founding of all public affairs organizations (as presented in table 2): the number of large foundations established in a given year. These data come from a 2007 report by the Foundation Center (available http:// foundationcenter.org/findfunders/) on the establishment of foundations that either (a) had more than $\$ 1$ million in assets as of $2004-5$ or $(b)$ made grants of at least $\$ 100,000$ at that time. This population is then projected backward in order to estimate the number of founding events since 1970. Using this measure as a control, we do not find a significant effect of foundation growth on the founding of all public affairs organizations or on the founding of NMAOs. However, when we include this control in our model of the founding of NMAOs engaged in government advocacy, we find a significant and very slightly positive effect $(P<.05)$, which indicates that above and 
Finally, we rely on a fourth data source in order to estimate the degree of public attention to the cause in question. Analyses have shown that media coverage is shaped by associational structure (Jacobs and Glass 2002). We measure public attention to each issue by creating annual counts of the number of New York Times stories devoted, respectively, to peace, women's issues, or human rights. Although the Times would perhaps be less appropriate if we were examining local-level social movement organizations, it serves well as an indicator of the national attention devoted to a given issue domain. The data we employ come from the Policy Agendas Project, which includes a random sampling of the Times index for each year from 1946 to 2003; we employ data on all years of interest in our time series. For the present analyses, we created yearly counts of the number of sampled Times articles that fit into each of the three areas we examine. ${ }^{38}$

beyond the other resource measures, NMAOs engaged in advocacy were supported by growth in the field of large grant-making foundations.

${ }^{38}$ Peace articles are those that included the words "war" or "peace," with reference to a specific war or conflict (e.g., articles that discussed the Peace Corps or the War on Drugs were excluded). Women's articles are those that made reference to "women," "abortion," or "reproductive rights." Human rights articles are those that include the terms "human rights," "amnesty," "political prisoner," or "refugee." We used keyword searches within the Policy Agendas Project New York Times database to identify these articles. 


\section{American Journal of Sociology}

TABLE A1

REPRESENTATIVE MEMbERShiP AND NONMEMBERShiP ORGANIZATIONS

\begin{tabular}{|c|c|}
\hline Membership & Nonmembership \\
\hline \multicolumn{2}{|l|}{ Peace organizations: } \\
\hline Arms Control Association & $\begin{array}{l}\text { Central Committee for Conscientious Ob- } \\
\text { jectors }\end{array}$ \\
\hline Clergy and Laity Concerned & Laucks Foundation \\
\hline $\begin{array}{l}\text { International Association of Educators } \\
\text { for World Peace }\end{array}$ & Peace Development Fund \\
\hline Students for Social Responsibility & WAND Fund \\
\hline War Control Planners & World Without War Council \\
\hline \multicolumn{2}{|l|}{ Women's organizations: } \\
\hline 9 to 5 & Center for Women Policy Studies \\
\hline Federally Employed Women & Ms. Foundation for Women \\
\hline National Abortion Rights Action League & National Women's Law Center \\
\hline National Organization for Women & $\begin{array}{l}\text { NOW Legal Defense and Educational } \\
\text { Fund }\end{array}$ \\
\hline $\begin{array}{l}\text { Women for Racial and Economic } \\
\text { Equality }\end{array}$ & $\begin{array}{l}\text { Women's Research and Education Insti- } \\
\text { tute }\end{array}$ \\
\hline \multicolumn{2}{|l|}{ Human rights organizations: } \\
\hline $\begin{array}{l}\text { American Christians for the Abolition of } \\
\text { Torture }\end{array}$ & Center for International Policy \\
\hline Amnesty International USA & $\begin{array}{l}\text { Church World Service Immigrant and Ref- } \\
\text { ugee Program }\end{array}$ \\
\hline Committee of Concerned Scientists & Death Penalty Information Center \\
\hline $\begin{array}{l}\text { National Coalition to Abolish the Death } \\
\text { Penalty }\end{array}$ & Blaustein Institute \\
\hline Physicians for Human Rights & U.S. Committee for Refugees \\
\hline \multicolumn{2}{|l|}{ Other public affairs organizations: } \\
\hline American Conservative Union & A. Philip Randolph Education Fund \\
\hline Americans for Democratic Action & Alliance for Consumer Rights \\
\hline Common Cause & $\begin{array}{l}\text { American Civil Liberties Union Founda- } \\
\text { tion }\end{array}$ \\
\hline John Birch Society & Industrial Areas Foundation \\
\hline $\begin{array}{l}\text { National Community Development As- } \\
\text { sociation }\end{array}$ & National Conference on Citizenship \\
\hline
\end{tabular}

\section{REFERENCES}

$\rightarrow$ Abel, Richard L. 1986. "The Transformation of the American Legal Profession." Law and Society Review 20:7-17.

Akey, Denise S., ed. 1981. Encyclopedia of Associations, 16th ed. Detroit: Gale.

$\rightarrow$ Andrews, Kenneth T., and Bob Edwards. 2004. "Advocacy Organizations in the U.S. Political Process.” Annual Review of Sociology 30:479-506.

$\rightarrow$ Andrews, Kenneth T., Marshall Ganz, Matthew Baggetta, Hahrie Han, and Chaeyoon Lim. 2010. "Leadership, Membership, and Voice: Civic Associations That Work." American Journal of Sociology 115:1191-1242.

$\rightarrow$ Archibald, Matthew. 2007. "An Organizational Ecology of National Self-Help/MutualAid Organizations." Nonprofit and Voluntary Sector Quarterly 36:598-621. 
$\rightarrow$ Barnett, William P., and Glenn R. Carroll. 1987. "Competition and Mutualism among Early Telephone Companies.” Administrative Science Quarterly 32:400-421.

$\rightarrow$ Baum, Joel A. C., and Christine Oliver. 1991. "Institutional Linkages and Organizational Mortality." Administrative Science Quarterly 36:187-218.

Baumgartner, Frank R. 2005. "The Growth and Diversity of U.S. Associations, 19562004: Analyzing Trends Using the Encyclopedia of Associations." Unpublished manuscript. Pennsylvania State University, Department of Political Science.

Baumgartner, Frank R., and Beth L. Leech. 1998. Basic Interests. Princeton, N.J.: Princeton University Press.

$\rightarrow$ Baumgartner, Frank R., and Jack L. Walker Jr. 1988. "Survey Research and Membership in Voluntary Associations." American Journal of Political Science 32:90828.

Berry, Jeffrey M. 1997. The Interest Group Society, 2d ed. New York: Longman.

. 1999. The New Liberalism. Washington, D.C.: Brookings Institution Press.

$\rightarrow$ Boli, John, and George M. Thomas. 1997. "World Culture in the World Polity: A Century of International Non-governmental Organization." American Sociological Review 62:171-90.

$\rightarrow$ Bosso, Christopher J. 2003. "Rethinking the Concept of Membership in Nature Advocacy Organizations." Policy Studies Journal 31:397-412.

Brint, Steven. 1996. In an Age of Experts: The Changing Role of Professionals in Politics and Public Life. Princeton, N.J.: Princeton University Press.

Brittain, Jack. 1994. "Density-Independent Selection and Community Evolution." Pp. 355-78 in Evolutionary Dynamics of Organizations, edited by J. A. C. Baum and J. V. Singh. New York: Oxford University Press.

Brulle, Robert, Liesel Turner, Jason Carmichael, and J. Craig Jenkins. 2007. "Measuring Social Movement Organization Populations: A Comprehensive Census of U.S. Environmental Movement Organizations.” Mobilization 12:255-70.

$\rightarrow$ Carroll, Glenn R., and Anand Swaminathan. 2000. "Why the Microbrewery Movement? Organizational Dynamics of Resource Partitioning in the U.S. Brewing Industry." American Journal of Sociology 106:715-62.

$\rightarrow$ Carroll, Glenn R., and James Wade. 1991. "Density Dependence in the Organizational Evolution of the American Brewing Industry across Different Levels." Social Science Research 20:271-302.

Center for American Women and Politics. 2010. "Women in the U.S. Congress." http:// www.cawp.rutgers.edu/fast_facts/levels_of_office/documents/cong.pdf.

Clemens, Elisabeth S. 1998. "Organizational Form as Frame: Collective Identity and Political Strategy in the American Labor Movement.” Pp. 205-26 in Comparative Perspectives on Social Movements, edited by Doug McAdam, John D. McCarthy, and Mayer N. Zald. New York: Cambridge University Press.

$\rightarrow$ Cress, Daniel M., and David A. Snow. 1996. "Mobilization at the Margins: Resources, Benefactors, and the Viability of Homeless Social Movement Organizations." American Sociological Review 61:1089-1109.

$\rightarrow$ Curran, Barbara A. 1986. "American Lawyers in the 1980s: A Profession in Transition." Law and Society Review 20:19-52.

Delgado, Gary. 1986. Organizing the Movement. Philadelphia: Temple University Press.

Della Porta, Donatella, and Mario Diani. 1999. Social Movements: An Introduction. Malden, Mass.: Blackwell.

$\rightarrow$ Dorfman, Marcia T. 1973. "Insurance Information Sources." Journal of Risk and Insurance 40:263-66.

Edwards, Bob, and Michael Foley. 2002. "Social Movement Organizations beyond the Beltway: Understanding the Diversity of One Social Movement Industry." Mobilization: An International Quarterly 8:87-107.

$\rightarrow$ Edwards, Bob, and Sam Marullo. 1995. "Organizational Mortality in a Declining Social 


\section{American Journal of Sociology}

Movement: The Demise of Peace Movement Organizations in the End of the Cold War Era." American Sociological Review 60:908-27.

$\rightarrow$ Eikenberry, Angela M. 2007. "Philanthropy, Voluntary Association, and Governance beyond the State: Giving Circles and Challenges for Democracy." Administration and Society 39:857-82.

Fisher, Dana. 2006. Activism, Inc. Stanford, Calif.: Stanford University Press.

Fisk, Margaret, ed. 1973. Encyclopedia of Associations, 8th ed. Detroit: Gale.

. 1976. Encyclopedia of Associations, 10th ed. Detroit: Gale.

$\rightarrow$ Freeman, Jo. 1973. "Origins of the Women's Liberation Movement." American Journal of Sociology 78:792-811.

Gale Research. 1995. Encyclopedia of Associations: National Organizations of the U.S. Machine-readable data file (CD-ROM). Detroit: Gale Research.

$\rightarrow$ Gray, Virginia, and David Lowery. 1996. "A Niche Theory of Interest Representation." Journal of Politics 58:91-111.

$\rightarrow$ Greve, Henrich R., Jo-Ellen Pozner, and Hayagreeva Rao. 2006. "Vox Populi: Resource Partitioning, Organizational Proliferation, and the Cultural Impact of the Insurgent Microradio Movement." American Journal of Sociology 112:802-37.

$\rightarrow$ Hagan, John, Marjorie Zatz, Bruce Arnold, and Fiona Kay. 1991. "Cultural Capital, Gender, and the Structural Transformation of Legal Practice." Law and Society Review 25:239-62.

$\rightarrow$ Hall, Richard L., and Alan V. Deardorff. 2006. "Lobbying as Legislative Subsidy." American Political Science Review 100:69-84.

Hannan, Michael, and Glenn R. Carroll. 1992. Dynamics of Organizational Populations. New York: Oxford University Press.

Hannan, Michael, and John Freeman. 1987. "The Ecology of Organizational Founding: American Labor Unions, 1836-1985." American Journal of Sociology 92:910-43.

- 1989. Organizational Ecology. Cambridge, Mass.: Harvard University Press.

Havens, John J., Mary A. O’Herlihy, and Paul G. Schervish. 2006. "Charitable Giving: How Much, by Whom, to What, and How?" Pp. 542-67 in The Non-profit Sector: A Research Handbook, edited by W. W. Powell and R. Steinberg. New Haven, Conn.: Yale University Press.

Heclo, Hugh. 1978. "Issue Networks and the Executive Establishment." Pp. 87-124 in The New American Political System, edited by A. King. Washington, D.C.: American Enterprise Institute.

Himmelstein, Jerome. 1990. To the Right. Berkeley and Los Angeles: University of California Press.

Horwitt, Sanford D. 1989. Let Them Call Me Rebel. New York: Knopf.

$\rightarrow$ Howard, Marc M., and Leah Gilbert. 2008. "A Cross-National Comparison of the Internal Effects of Participation in Voluntary Organizations." Political Studies 56: $12-32$.

Howard, Philip N. 2006. New Media Campaigns and the Managed Citizen. New York: Cambridge University Press.

$\rightarrow$ Jacobs, Ronald N., and Daniel J. Glass. 2002. "Media Publicity and the Voluntary Sector: The Case of Nonprofit Organizations in New York City." Voluntas 13:23552.

Jaszczak, Sandra, ed. 1996. Encyclopedia of Associations, 31st ed. Detroit: Gale.

$\rightarrow$ Jenkins, J. Craig, and Craig M. Eckert. 1986. "Channeling Black Insurgency: Elite Patronage and Professional Social Movement Organizations in the Development of the Black Movement." American Sociological Review 51:812-29.

Jenkins, J. Craig, and Abigail Halcli. 1999. "Grassrooting the System? The Development of Social Movement Philanthropy, 1953-1990.” Pp. 227-56 in Philanthropic Foundations, edited by E. C. Lagemann. Bloomington: Indiana University Press.

Johnson, Erik, and John D. McCarthy. 2004. "The Sequencing of Transnational and National Social Movement Mobilization: The Organizational Mobilization of the 
Global and U.S. Environmental Movements." Pp. 71-93 in Transnational Protest and Global Activism, edited by Donatella Della Porta and S. Tarrow. Lanham, Md.: Rowman \& Littlefield.

Jones, Bryan D., and Frank R. Baumgartner. 2005. The Politics of Attention. Chicago: University of Chicago Press.

Jordan, Grant, and William A. Maloney. 1997. The Protest Business? Mobilizing Campaign Groups. Manchester: Manchester University Press.

Keck, Margaret E., and Kathryn Sikkink. 1998. Activists beyond Borders. Ithaca, N.Y.: Cornell University Press.

Levitsky, Sandra R. 2007. "Niche Activism: Constructing a Unified Movement Identity in a Heterogeneous Organizational Field." Mobilization 12:271-86.

Lippmann, Walter. 1966. Public Opinion. New York: Free Press.

Loomis, Burdett A., and Allan J. Cigler. 1995. "Introduction: The Changing Nature of Interest Group Politics." Pp. 1-32 in Interest Group Politics, 4th ed., edited by Allan J. Cigler and Burdett A. Loomis. Washington, D.C.: Congressional Quarterly Press.

$\rightarrow$ Lowery, David, and Virginia Gray. 1998. "The Dominance of Institutions in Interest Representation: A Test of Seven Explanations." American Journal of Political Science 42:231-55.

Mansbridge, Jane J. 1986. Why We Lost the ERA. Chicago: University of Chicago Press.

$\rightarrow$ Martin, Andrew W., Frank R. Baumgartner, and John D. McCarthy. 2006. "Measuring Association Populations Using the Encyclopedia of Associations: Evidence from the Field of Labor Unions." Social Science Research 35:771-78.

$\rightarrow$ Martin, William. 1999. "The Christian Right and American Foreign Policy." Foreign Policy 114:66-80.

McAdam, Doug, and W. Richard Scott. 2005. "Organizations and Movements." Pp. 4-40 in Social Movements and Organization Theory, edited by Gerald F. Davis, Doug McAdam, W. Richard Scott, and Mayer N. Zald. New York: Cambridge University Press.

$\rightarrow$ McAdam, Doug, and Yang Su. 2002. "The War at Home: Antiwar Protests and Congressional Voting, 1965 to 1973." American Sociological Review 67:696-721.

McCarthy, John D. 2005. "Persistence and Change among Nationally Federated Social Movement Organizations." Pp. 193-225 in Social Movements and Organization Theory, edited by Gerald F. Davis, Doug McAdam, W. Richard Scott, and Mayer N. Zald. New York: Cambridge University Press.

$\rightarrow$ McCarthy, John D., and Edward T. Walker. 2004. "Alternative Organizational Repertoires of Poor People's Social Movement Organizations." Nonprofit and Voluntary Sector Quarterly 33:97S-119S.

McCarthy, John D., and Mayer N. Zald. 1973. The Trend of Social Movements in America. Morristown, N.J.: General Learning Press.

$\rightarrow$. 1977. "Resource Mobilization and Social Movements: A Partial Theory." American Journal of Sociology 82:1212-41.

McFarland, Andrew S. 1984. Common Cause. Chatham, N.J.: Chatham House.

$\rightarrow$ McGann, James G. 1992. "Academics to Ideologues: A Brief History of the Public Policy Research Industry." PS: Political Science and Politics 25:733-40.

Meyer, David S. 1990. A Winter of Discontent: The Nuclear Freeze and American Politics. New York: Praeger.

$\rightarrow$ Meyer, David S., and Nancy Whittier. 1994. "Social Movement Spillover." Social Problems 41:277-98.

$\rightarrow$ Meyer, John W., and Brian Rowan. 1977. "Institutionalized Organizations: Formal Structure as Myth and Ceremony." American Journal of Sociology 83:340-63.

$\rightarrow$ Minkoff, Debra C. 1994. "From Service Provision to Institutional Advocacy: The Shifting Legitimacy of Organizational Forms." Social Forces 72:943-69. 


\section{American Journal of Sociology}

- 1995. Organizing for Equality. New Brunswick, N.J.: Rutgers University Press. . 1997. "The Sequencing of Social Movements." American Sociological Review 62:779-99.

$\rightarrow \longrightarrow$ 1999. "Bending with the Wind: Strategic Change and Adaptation by Women's and Racial Minority Organizations." American Journal of Sociology 104:1666-1703.

—. 2002. "Macro-organizational Analysis." Pp. 260-85 in Methods of Social Movement Research, edited by B. Klandermans and Suzanne Staggenborg. Minneapolis: University of Minnesota Press.

$\rightarrow$ Minkoff, Debra C., Silke Aisenbrey, and Jon Agnone. 2008. "Organizational Diversity in the U.S. Advocacy Sector." Social Problems 55:525-48.

$\rightarrow$ Olzak, Susan, and Emily Ryo. 2007. "Organizational Diversity, Vitality and Outcomes in the Civil Rights Movement." Social Forces 85:1561-92.

Osterman, Paul. 2002. Gathering Power: The Future of Progressive Politics in America. Boston: Beacon.

Pair, Mary Wilson, ed. 1978. Encyclopedia of Associations, 12th ed. Detroit: Gale.

Peschek, Joseph G. 1987. Policy-Planning Organizations. Philadelphia: Temple University Press.

Prewitt, Kenneth. 2006. "Foundations." Pp. 355-77 in The Nonprofit Sector: A Research Handbook, 2d ed. New Haven, Conn.: Yale University Press.

$\rightarrow$ Putnam, Robert D. 1995. "Bowling Alone: America's Declining Social Capital." Journal of Democracy 6:65-78.

. 2000. Bowling Alone. New York: Simon \& Schuster.

Rao, Hayagreeva, and Eric Nielsen. 1992. "An Ecology of Agency Arrangements: Mortality of Savings and Loan Associations, 1960-1987." Administrative Science Quarterly 37:448-70.

Reitzes, Donald C., and Dietrich C. Reitzes. 1987. The Alinsky Legacy. Greenwich, Conn.: JAI.

Rich, Andrew. 2004. Think Tanks, Public Policy, and the Politics of Expertise. New York: Cambridge University Press.

Ruffner, Frederick G., et al., eds. 1964. Encyclopedia of Associations, 4th ed. Detroit: Gale.

$\rightarrow$ Salisbury, Robert H. 1984. "Interest Representation: The Dominance of Institutions." American Political Science Review 78:64-76.

$\rightarrow$ Sampson, Robert J., Doug McAdam, Heather MacIndoe, and Simon Weffer. 2005. "Civil Society Reconsidered: The Durable Nature and Community Structure of Collective Civic Action." American Journal of Sociology 111:673-714.

Shaiko, Ronald G. 1999. Voices and Echoes for the Environment: Public Interest Representation in the 1990s and Beyond. New York: Columbia University Press.

$\rightarrow$ Singh, Jitendra V., and Charles J. Lumsden. 1990. "Theory and Research in Organizational Ecology." Annual Review of Sociology 16:161-95.

Skocpol, Theda. 1999a. "Advocates without Members: The Recent Transformation of American Civic Life." Pp. 461-509 in Civic Engagement in American Democracy, edited by Theda Skocpol and Morris P. Fiorina. Washington, D.C.: Brookings Institution Press.

— 1999b. "Associations without Members." American Prospect (July/August): 6673.

2003. Diminished Democracy. Norman: University of Oklahoma Press. 2004a. "The Narrowing of Civic Life." American Prospect (June): A5-A7. 2004b. "Voice and Inequality: The Transformation of American Civic Democracy." Perspectives on Politics 2:3-18.

$\rightarrow$ Skocpol, Theda, Rachel V. Cobb, and Casey A. Klofstad. 2005. "Disconnection and Reorganization: The Transformation of Civic Life in Late-Twentieth-Century America." Studies in American Political Development 19:137-56.

Smith, Jackie. 2005. "Globalization and Transnational Social Movement Organiza- 
tions." Pp. 226-48 in Social Movements and Organization Theory, edited by Gerald Davis, Doug McAdam, W. Richard Scott, and Mayer N. Zald. New York: Cambridge University Press.

$\rightarrow$ Sobieraj, Sarah. 2006. "The Implications of Transitions in the Voluntary Sector for Civic Engagement: A Case Study of Association Mobilization around the 2000 Presidential Campaign." Sociological Inquiry 76:52-80.

$\rightarrow$ Soule, Sarah A., and Brayden G. King. 2008. "Competition and Resource Partitioning in Three Social Movement Industries.” American Journal of Sociology 113:15681610.

Southern Poverty Law Center. 2008. "Morris Dees Biography.” http://www.splcenter .org/center/history/dees.jsp.

$\rightarrow$ Staggenborg, Suzanne. 1988. "The Consequences of Professionalization and Formalization in the Pro-choice Movement." American Sociological Review 53:585-605.

Strolovitch, Dara. 2007. Affirmative Advocacy: Race, Class, and Gender in Interest Group Politics. Chicago: University of Chicago Press.

$\rightarrow$ Suchman, Mark C. 1995. "Managing Legitimacy: Strategic and Institutional Approaches." Academy of Management Review 20:571-610.

$\rightarrow$ Tauber, Steven C. 1998. "On Behalf of the Condemned? The Impact of the NAACP Legal Defense Fund on Capital Punishment Decision Making in the U.S. Courts of Appeals." Political Research Quarterly 51:191-219.

$\rightarrow$ Taylor, Verta. 1989. "Social Movement Continuity: The Women's Movement in Abeyance." American Sociological Review 54:761-75.

$\rightarrow$ Thomas, Sue. 1991. "The Impact of Women on State Legislative Policies." Journal of Politics 53:958-76.

Verba, Sidney, and Norman H. Nie. 1972. Participation in America. New York: Harper \& Row.

$\rightarrow$ Walker, Edward T. 2009. "Privatizing Participation: Civic Change and the Organizational Dynamics of Grassroots Lobbying Firms." American Sociological Review 74:83-105.

$\rightarrow$ Walker, Jack. 1983. "The Origins and Maintenance of Interest Groups in America." American Political Science Review 77:390-406.

- 1991. Mobilizing Interest Groups in America. Ann Arbor: University of Michigan Press.

Warren, Mark R. 2001. Dry Bones Rattling. Princeton, N.J.: Princeton University Press.

Weir, Margaret, and Marshall Ganz. 1997. "Reconnecting People and Politics." Pp. 149-71 in The New Majority: Toward a Popular Progressive Politics, edited by Stanley B. Greenberg and Theda Skocpol. New Haven, Conn.: Yale University Press. 